\title{
吾邦二於ケル馬ノ流行性腦炎， 原因學的研究
}

(昭和 12 年 2 月 6 日受付)

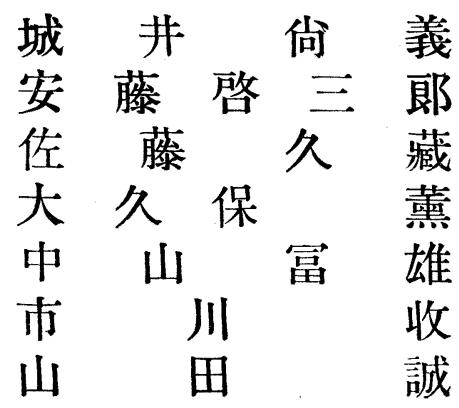

\section{緒言}

昭和 10 年初夏ヨリ初秋, 候. 人間ノ夏期腦炎ノ流行ト時キ同フシテ. 殆ンド本邦 ノ全部二馬ノ腦炎ガ大二流行シ. 農林省ノ調查ニヨルト.患馬ノ總數ハ 1,180 頭二及 ンデ居ルガ. 賽際ハえレヨリモ尙ホ相當多カッタト思ハレル。當時軍馬モ亦其侵襲タ 免レズ．陸軍當局ノ報告ニヨルト．第 10 . 第 16 . 第 3 . 第 1 . 近衙. 第 14 . 第 2 . 第 8 / 各師管下二於テ 168 頭ノ馬ガ之レニ罹ツタ。昭和 11 年, 夏ニモ佐賀. 福岡. 香 川. 杤木. 茨城. 北海道等二同症發生シ. 患馬ノ數八二百數十頭二達シタ模樣デアル。

文獻キ按ズル二、昭和 10 年ノ樣ナ大流行コソ未轓有デハアルガ. 明治 32 年二東 京. 福島. 宮城ノ諸府縣二. 又明治 38 年ニ八山形縣ノ一部二同樣ノ病氣ガ發生シタ。 其他北儿州. 殊二筑後河,下流. 福岡. 佐賀兩縣ノ界チ流ル、區域ノ兩沿岸二八. 每 年夏ニナルト。此種ノ馬ノ病氣ガ地方病性二發生スルコトガ.古クョリ知ラレテ居ル。 然シナガラ從來其病原ノ研究ガ行ハレナカツタ䉆メ二. 以上ハ何レモ同一ノ疾病デア ルカ否ヤハ不明デアル。

外國二於ケル馬ノ流行性腦炎八原因學的ノ見地ヨリシテ．吾人八今日之レチ數種二 區別スル。換言セバ本症ハ多元性ノ疾病デアル。最モ古クョリ知ラレテ居ルノ八. ドィッノ東南部ノ一定地方二地方病性トナツテ發生スル所ノ所謂 Borna 病デアル。 此病氣ノ原因ハ久シク不明デアッタガ. 1925 年 Zwick 及 Seifried (1) ガ本病子家鬼 
二接種スルコトニ成功スルト同時二病原體ハ・種ノ滤過性病毒ナルコトガ明ニナリ. 其後 Zwick, Seifried 及 Witte (2), Ernst 及 Hahn (3), Nicolau 及 Galloway ${ }^{(4)}$ 八 そレチ承認シタノミナラズ・何レモ知胃ノ淮展二貢獻シタ。ソレ等/研究，成績キ綜 合スルト. 此病毒八馬ノ外. 家鬼. 海猽. 大黑鼠. 猿. 緬羊二對シテ病原性キ有シ. 腦內接種, 外. 腰椎內. 眼前房內. 靜脈內. 鼻腔內接種二由リテ之等ノ動物二腦炎 起サシメ得ル。就中鬼ハ最モ感受性二富え。賽驗二ハ此動物ガ最モ適賞デアル樣二見 エル。但 シ其潛伏期八割合二長ク. 馬八 7 週. 鬼 $3-4$ 週. 海猽 3 週一 1 年. 大黑鼠 3 -10 週. 二十日鼠 5-18 週. 猿 60-70 日等デァル。

ドイツデ Zwick ガボルナ病キ鬼二接種スルコトニ成功シタト殆ド同時二 Moussu 及 Marchand ${ }^{(5)}$ ハフランス二發生シタ馬, 流行性腦炎チ研究シ。患馬, 腦乳劑鬼 八眼前房內二接種シテ感染七シメ得タガ. 其研究成績タ報告スルニ當リ. Maladie de Borna ノ名キ以テシタルニ對シ. Zwick und Seifried ${ }^{(1)}$ ハランスノソレハ病 理解剖學的差異ノ外. 兔二於ケル濳伏期ノ著シク短カイ點(僅二 3 日) キ以テボルナ病 ニアラズト抗議シタ。其後 Arndt ${ }^{(7)} モ$ 亦 Zwick 及 Seifried ノ說二贊成シタ。若シ コレガボルナ病ニアラズトスルナラバ，ボルナ病以外二モ馬ノ流行性腦炎ノ存在スル コトガ明ニサレタ最初ノモノト謂ハネバナラヌ。

次 $=1930$ 年ト 31 年二北米カリフォルニア州二馬，腦脊髓炎，大流行ガ起リ．無虑 1 萬頭以上/馬ガそレニ罹ツタ。Meyer, Haring 及 Howitt ${ }^{(7)}$ ガ最先キニ之レタ研 究シ.一種ノ滤過性病毒き以テ其原因卜認メタガ. 此「ヴゃールス」ハボルナ病ノソレ トハー致七ヌ。郎チボルナ病毒八海猽ヨリモ兔二對シテョリ强キ病原作用ォ呈スルニ アメリカノ八正二相反スルノミナラズ. 其潛伏期八著シク短ク海猽. 鬼共 $=1-3$ 日 デアル。加之 Howitt ${ }^{(8)}$ 八免疫學的二此兩病毒,同一ナラザルコトキ明ニシタ。

1933 年二又々アメリカ二. 然シ此度八Virginia, Maryland 及 Delaware 等東部 諸州二馬腦炎ノ大流行ガアッタ。Ten Broeck 及 Merril (9) /研究シタ所二據ルト. 病馬, 臨林的所見八其經過ガ少シク短イコトノ外. 西部諸州二於テ流行シタモノト何 等異ナル所ナク，其病毒，性質モ西部株二同ジク．海㩧八最モ感染シ易ク。一十日鼠 最モ罹り難ク．鬼八其中間二在ル。然ルニモ拘ラズ兌疫學的見地ヨリスレバえレハ各 々異ナル病毒デアル。Howitt (8) ，其後八研究二據ルモ。東西兩株八冕疫學的二判然 卜區別スルコトガ出來ル。爾來アメリカデハえレチボルナ病ト唱へズ．單二 equine encephalomyelitis ト稱シ。而シテ其病原タル「ヴールス」キ西株及ビ東株ト區別シテ 居火。 
1933 年アルゼンチンニモ馬, 腦炎が流行シタガ. Rosenbusch ${ }^{(10)}$ 人研究シタ所デ

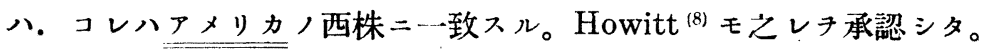

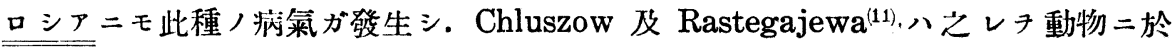
ケル接種成績/差異ニヨリ 3 型二區別スルコトガ出來ルト謂ツテ居ルケレドモ. 少ク トモ此內ノ2型ハボルナ病卜同一ノ樣二思へル。

吾邦二於ケル流行性馬腦炎, 原因學的研究成績, 今日迄二發表サレタモノ八唯江 本. 近藤. 渡䢧及松本 ${ }^{(12)}$ ノソレアルノ 氵デアル。氏等八昭和 10 年福岡. 佐賀. 杤木. 大阪ノ諸府縣二於テ發生シタ患馬ノ中心神經系ノ病理組織學的檢索チ行フト同時二。 其腦キ馬. 鬼. 海猽. 二十日鼠ノ頭蓋腔內二接種シタガ. 其結果ハ『不規則』デ. 然カ モ一间モ畺ノ累代接種二成功セズ. 著者等八其結論二於テ『甚ダ遗憾乍ラ病毒ヲ分離 シ得ズ』ト述べタ。

私共八昭和 10 年ニ八親シク患馬丹觀察シ. 屍體丹.剖檢スルノ機會チ得ナンダガ. 幸二陸軍獸醫學校ノ过敎官 $コ 2$ 頭ノ病馬ノ腦ノ一片キ貴ヒ受ケルコトガ出來タノデ

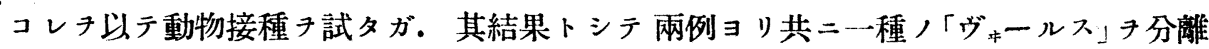
シ得タ。當時此「ヴャールス」ガ馬腦炎ノ原因體ナリヤ否ヤキ決スベキ實驗が佔不充分 デアリ. 殊二馬へノ接種ガ不成功二終タノデ. 其發表タ暫時保留シタノデアル。然ル 二昨昭和 11 年，夏. 佐賀縣下二於テ 3 例ノ病馬 解剖シ. 研究材料丹探取スルノ機 會子得タガ. 此中 2 例ヨリ又々前年ノソレト同一ノ病毒ヨ分離シタノえナラズ. 種々 ナル實驗ノ結果. 此「ヴャールス」コソ吾邦ニ於ケル馬流行性腦炎, 原因體ナリト钽定 スルニ至ツタノデ、弦ニえレタ報告スル次第デアル。

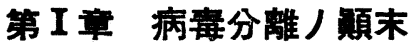

先ヅ「ヴょールス」分離ノ顛末カラ述べル。

第 1 信武株

本株ハ病馬信武號ヨリ分離サレタ。此病馬八宇都宮ノ騎兵第 18 聯隊所屬 ノ北海道

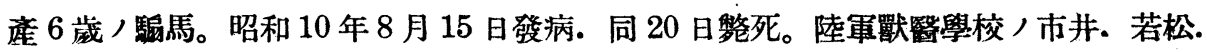
加藤 ${ }^{(13)}$ ，報告二ヨルト．本馬八嗅三角. 大腦脚. 尾狀核. 延娟等二血管周園細胞浸潤 ガ見ラレタ。

陸軍獸醫學校ノ过教官ヨリ变與サレタ材料ハ「グリセリン」中二浸漬サレテアリ。大 腦ノ一部デアルラシイガ. 何レノ部分デアルカ詳デナイ。試二其一小片フ培養シテ見 タノニ. 可ナリ澤山ナ雜菌ノ混入七ルチ知ツタノデ.えレタ $\mathrm{pH} 7.7$ 人緩衝溶液デ約 


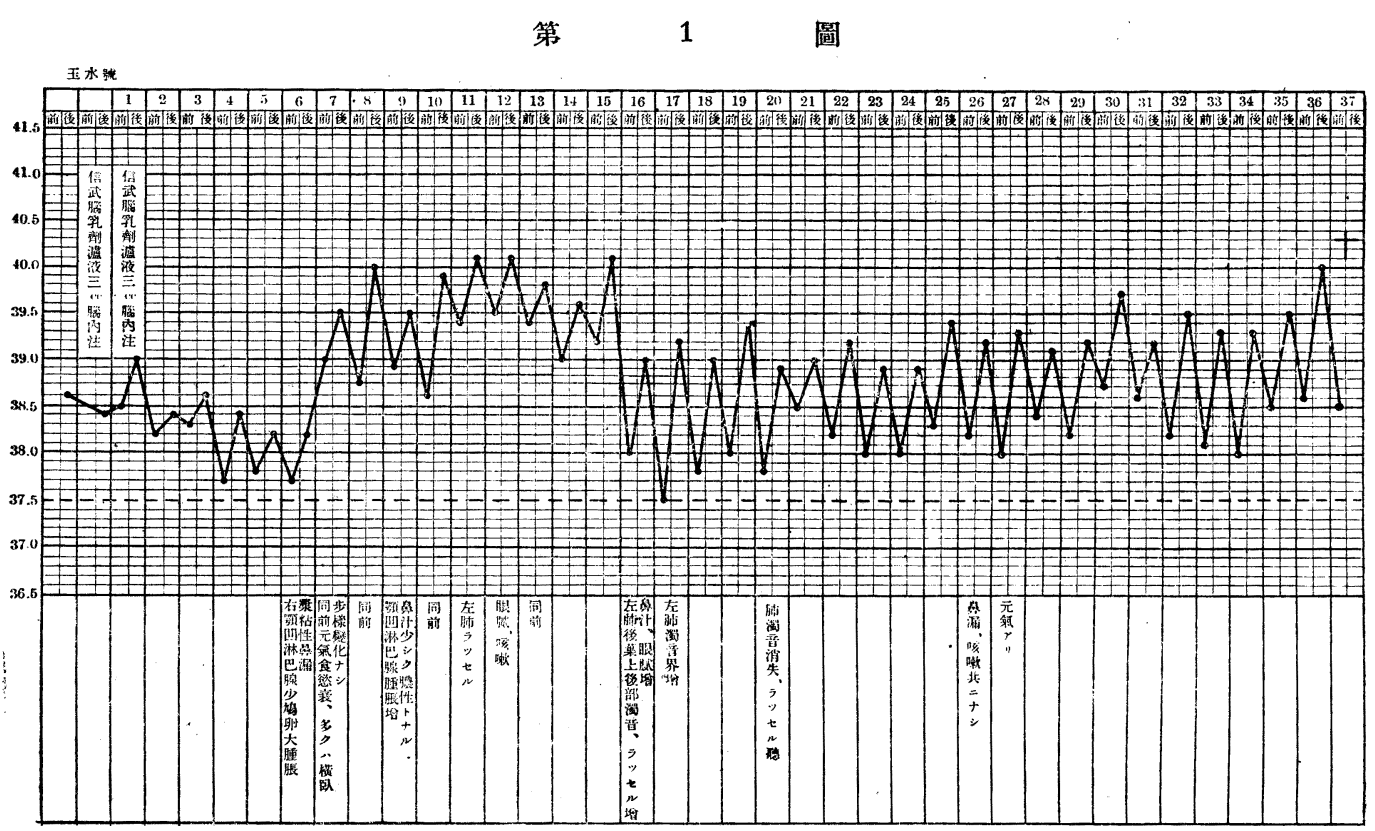

30 倍ノ乳劑キ造リ. Berkefeld V デ滤過シ. 其 3 c.c. キ傳染病研究所內デ出產シタ生 後 2 ケ月, 乳駒玉水號, 腦內二注入シタ。馬,腦內接種八何分二モ初メテノコトナ, デ、技術二少シク不安心ナ點ガアッタノデ．念ノ䉆メ柆日更二反對側二同量ノ注入テ 反復シタ。吾々ノ考デハ. 若シ此病氣ガドイツヤ北米二發生シタモノト同樣ニ「ヴょー ルス」ニ由テ起ルモノナラバ．斯クシテ恐ラクハ此駒二實驗的腦炎テ起サシメ得ルダ ラウ.サウシタナラバ，ソレヨリ病毒ノ分離キ試えヤウ．換言セバ．コレニヨリラ病 毒ヨリ雜菌キ除去セントシタノデアル。駒ハ第 2 回接種後 5 日フ經テ體溫ガ上昇シ始 メタ(第 1 圖參照)。弦二於テ愈 ? 兩 3 日ノ內二八何等カノ中心神經系, 障碍二基ク症 狀チ發顯スルモノト堅ク信ジタ。然ルニ此豫想八全然裏切ラレ. 發熱ト同時二鼻漏. 顎凹淋巴腺ノ腫脹等上部呼吸道ノ炎症キ標示スル症狀き顯ハシ。之等ノ症狀ガイツマ デモ持續スルダケデ．何等神經症狀ガ顯ハレテ來ナイ。熱モドィッャ北米，馬腦炎毒 接種/場合卜異ナリ嵇留性デ。イッマデモ下降ノ模樣ガナイ。但シ腺疫デナイコトハ 敢テ細菌學的檢查キ待ツマデモナク．鼻汁ノ性質ヤ淋巴腺ノ腫レ具合デ明デァッタ。 第 15 日二至り左肺ノ後葉ノ上後隅二於テ「クル.,プ」性肺炎ノ症狀. 郎于打診音溷濁. 水泡性「ラッセル」徵ジ。此時分カラ熱型ガ少シク變ツテ來テ、體溫ハ少シク低ク 目ニナツダガ、一日中ノ㭌降が著明デ. 所謂弛張熱型トナツタ。肺ノ濁音八第 18 日 頃ニハ能ク分ラ又程度トナツタガ. 鼻汁ヤ咳嗽ハ第 $24-5$ 日頃迄見ラレ. 爾來コレガ 
消失スルト共ニ. 元氣食篎八漸次改善セラレ.或ハ治癒スルノデハナイカト思ハレテ 居ッタノ二、第 37 日二於テ高熱,下二突然整死シタ。郎千腦內接種後, 症狀八主卜 シテ呼吸器疾患ノソレニ終始シ. 毫モ神經症狀キ認メナカツタ。サラバト謂ツテ「ク ルップ」性肺炎トシテハ餘程非定型的デアル。

死後直チ二解剖シタガ. 死因タリト認メ得ベキ何等特異,臟器病キ發見シ得ナカッ タ。腦及ビ脊髓ハ肉眼的ニハ常態デアツタ。左肺後葉ノ後上部. 生活間「クルップ」性 肺炎ノ徵き認メタ部位八暗褐赤色ノ無氣肺き形成シテ居ツタ。其他ノ變狀トシテ稍? 注目チ惹イタモノ八殆ンド全身, 淋巴腺ノ水腫性腫脹. 充血又八出血卜心筋ノ稍了高 度ノ棞濁デアッタ。サリナガラ感染脾ハナク. 漿液膜其他ノ出血斑モナク. 肝及ビ腎 八肉眼的ニハ常態デアッタ。其後ノ組織學的檢查二於テハ腦炎モ脊髓炎モ證明サレナ カッタ。要スル二死因八遂二不明二終ツタノデァル。

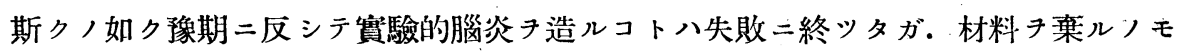
何トナク惜シイノデ. 鬼二角試二脾. 淋巴腺及ビ「アンモン」角ノ約 10 倍食監水乳劑

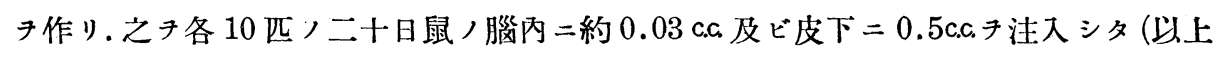

第2 圖信武株系圖

信(組+)

永(組一)

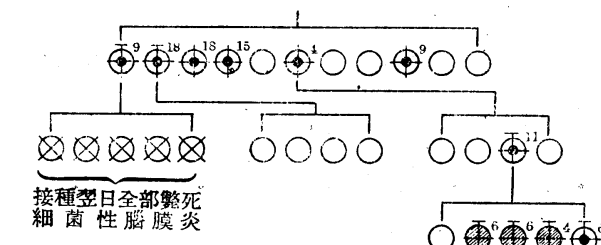

以下各表ノ凡例

定型的腦炎症狀

(?)腦炎疑症狀

○健 康

+ 獘 死

干 殺

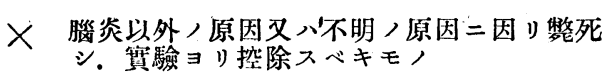

符合右肩，數字八生存日數. 但激死，場合八 其發見ノ日 慗死日卜見做入 符合右下隅ノ十又八ー八病理組糡學的所見八陽 性又八陰性
ノ各乳剂入調製後直于二好氣性及 ビ嫌氣性培養フ行フタガ. 何レモ 無菌デアツタ。サラバ本乳駒ノ死 因ガ細菌性敗血症デナカツタコト 八此點カラ明デアッテ．隨テ死因 八谷、不明トナツタ)。脾臟及ビ 淋巴腺ノ乳劑フ接種サレタ二十日 鼠,內二八取り立テ、謂つ程, 異 狀き顯ハス者ガナカツタガ. 意外 こモ腦キ接種サレタ二十日鼠,內 カラ妙ナ症狀. 郎于吾々ガ其後猬 型卜唱へルコトニシタ所ノ毛逆 立テ.背彎シ.元氣ガナクナリ. 靜二蹼ルモノガボツボツ顯ハレテ 來. 其或者八整死シタ。之等八內

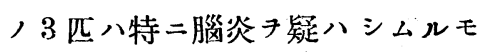
ノガアツタノデ．其腦チ剔出シ。 


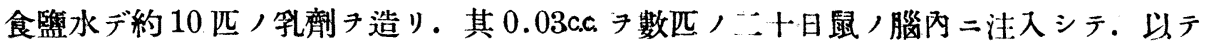
次代接種き試タガ.内 1 匹カラ第 2 圖二示ス樣ナ經路キ以テ二十日鼠，腦內二一種， 腦炎毒キ固定シ得タ. 即チ病毒, 所謂分湤が出來タ。本株八爾來 20 數代二十日鼠二 累代接種サレ. 以テ今日二至ツテ居ル。

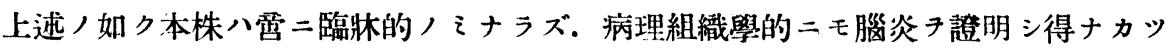
タ駒ノ腦ヲ接種サレタ二十日鼠カラ出テ來タ。此「ヴールス」ハ果シテ患馬信武號二 由來シタモノデアラウ乎. 換言セバ元々信武ノ腦髓內二存在シタモノデアラウ乎。余 等モ當時ハ大ニ之レキ疑フタノデアルガ. 今日デハ其然ルコトチ確信シテ居ル。然ラ バ病毒八玉水號ノ腦內二於テ如何ナル狀態ニアツタノデアラウ乎。注入サレタ病毒が 增殖スルコトナク. 又死隇スルコトナシニ 30 餘日間單二生存シテ居ッタノ二過ギナ イ乎. 或八感染ハシタガ未ダ兟伏期中ニアッタノデァラウ乎. 或八無症狀感染デアッ タノデァラウ乎、之等八今日全然不明デアル。又該乳駒ノ病氣八腦炎病毒二由テ惹起 サレタノデアラウ乎.ソレトモ腦炎病毒ト八何等ノ關係ナク，偶然他病二罹患シタ， デアラウ乎. そレヌ詳ニスルコトガ出來邓。然シ此事賽八本症, Pathogenesis ヤ疫 學ノ上二何等カ重要ナ示唆チ含ンデ居ル樣ナ感ガアルノデ. 今後ノ研究ノ參考ニナル ト思フテ事實キ有リ，儘二稍?詳シク陳述シテ置ク次第デアル。

\section{第 2 朝霧株}

株祖朝霧號八杤木縣杤木町二於テ馆司育セラレテ居ツタ北海道產ノ3 歲牡馬。昭和 10 年9月21日發病(陸軍獸醫學校，見解二依ルト此日附八確デナイ). 研究用トシテ陸軍 獸醫學校へ買入レ.翌 22 日同校二於テ殺サレタ。同校市井. 若松. 加栐 ${ }^{(13)}$ / 報告二據 nト. 其嗅球. 前頭葉. 覻頂葉. 頻䫫葉. 後頭葉. 大腦脚. 尾狀核. 安門角. 視丘. 小腦及ビ腰髓二高度, 血管周圍細胞浸潤ガ見ラレタ。

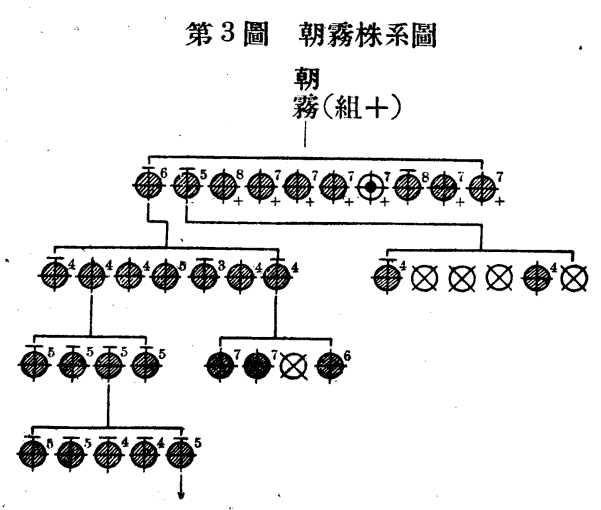

吾々ガ貴ヒ受ケタノ八此馬ノ安門角 ノ一片デアル。此材料八培養上無菌ナ ルコトキ知ツタカラ. 直チ二食監水デ 10 倍乳剂トナシ。 10 匹ノ 三十日鼠二 其 0.03c.a 腦內二。 $0.5 \mathrm{ccc}$ \%皮下二注 射シタ。然ルニ本例八甚ダ特殊,例デ アッテ. 全部 , 二十日鼠ガ 5一6 日， 濳伏期 經テ定型的症狀 シ. 頗儿容易二病毒, 分麇 ガ出來タ 
(第 3 圖參照)。本株モ爾來二十日鼠二累代接種サレ、現今 20 數代二及ンデ居ル。

\section{第 3 宮原株}

株祖八佐賀縣三養基郡北茂安村字東尾． 官原某飼育ノ北海道產 2 歲牡馬。一昭和 11 年 8 月 22 日發病. 24 日未明整死。死後 6 時間テ經テ解剖。頭蓋膑內二テ右大腦牛球 上面ノ前部無菌的二切リ取り．50\%「グリセリン」中二投入シテ東京二空輸。同月 26

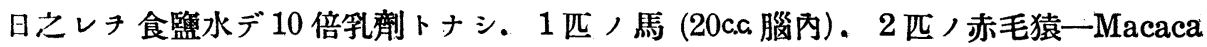

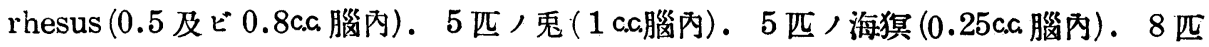

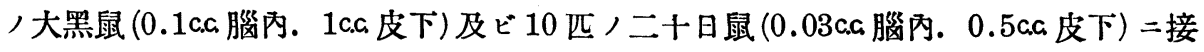
種シタ。馬. 鬼. 海猽及ビ大黑鼠二八何レモ異狀タ認メナンダ。猿ハ 1 匹八第 5 日二 他ノ 1 匹八第 6 日二一過性ノ輕熱 $\left(39^{\circ} 1\right.$ 又ハ $\left.39^{\circ} 5\right)$ チ發シタ以外ニ八何等ノ病徵 顯八 サナカッタ。然ル二二十日鼠中 2 匹ノ腦炎ラシイ症狀呈スルモノガ出タガ. 其內， 1 匹カラ第 4 圖二示ス如キ經路キ以テ病毒ガ分離サレタ。

第 4 圖 宮原株系圖

(第 1 回分離)

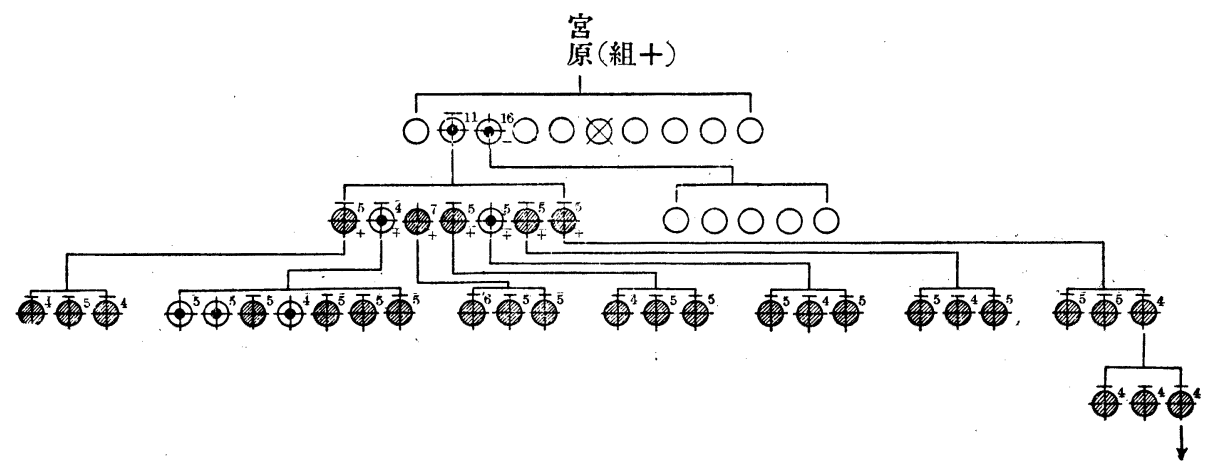

（第 2 间分離）

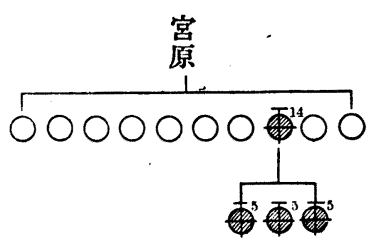

此馬腦ハ東京到著後「グリセリン」ニ浸清シタ谥零 度,冷藏庫二保存サレテアッタガ. 病毒生存ノ模樣 チ知ランが䉆メ。探收後約 1 ケ月タ經タル9月22日 再ビ二十日鼠接種キ試にタ。郎チ前回同樣 10 匹， 二十日鼠二馬腦，10 倍食監水乳劑 $0.03 \mathrm{ca}$ 斗腦內二

$0.5 \mathrm{ca}$ チ皮下二注射シタ。日々些細二動物キ觀察シテ居ツタガ.ナカナカ腦炎ラシイ 症狀旺スルモノガ出テ來ナイ。然ル二第 13 日二至ツテ 1 匹ノ二十日鼠ハ瘦㓱シテ 元氣ガナク．靜止シテ動カウトシナイノチ發見シタ。柆日ニナルト．此鼠八定型的腦 炎症狀顯ハシテ居ルノチ見タ。郎チ全身麻痹シ。死期迫レルモノアルチ思ハシメ 
タ。仍テ之レチ殺シ. 其腦ノ乳劑キ 3 匹ノ二十日鼠ノ腦内二接種シタノニ. 3 匹ト、 4 日ノ潜伏期 $キ$ 以定型的腦炎症狀き呈シタ。郎チ本例モ初代接種力ラ定型的症狀， 顯ハレタ 1 例デアル。

株祖患馬ノ腦及ビ春髓ノ組織學的檢查二於テ嗅球. 前頭葉. 前中心廻轉.「レンズ」 核. 尾狀核. 後中心廻轉. 視丘. 安門角. 後頭葉. 大腦脚。腦橋. 顓髓及ビ胸髓二輕 度乃至中等度ノ血管周圍細胞浸潤及ビ「グリア」結節ヨ．又嗅球．前頭葉．後頭葉．前 中心廻轉及ビ後中心廻轉二輕度, 腦膜炎ガ存在シテ居ツタ。

第 4 大坪株

本株ハ佐賀縣佐賀郡中川副村字猗ヶ江. 大坪某飼育ノ北海道產 2 歲牡馬 $コ$ 分雄サ レタ。該馬八昭和 11 年 8 月 23 日發病. 同月 25 日放血致死. 直チ二解剖. 前例同樣右 大腦牛球ノ前上部き無菌的二剔出. $5 \% 「$ グリセりン」中ニ浸漬シテ空輸. 同月 27 日東 京二於テ食監水デ 10 倍乳劑トナス。培養無菌。28 日 1 頭ノ馬(20c.c. 腦內)．2匹ノ赤

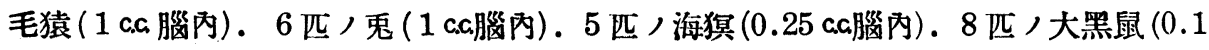
c.c.腦內) 及ビ 10 匹ノ二十日鼠二接種シタ。二十日鼠ハ 5 匹二八 0.03 c.c. キ腦內二。 0.5

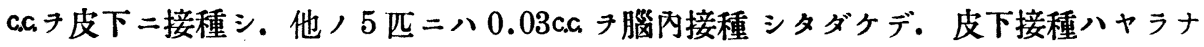
カッタ。馬. 兔. 海猽及ビ 大黑鼠ハ凡テ無反應。猿ハ 1 匹ダケ第 7 日二體溫が突然 $40^{\circ} 2$ 二上昇シ，第 9 日二平溫二復シ．爾後ハ健康ヨ保持シタ。然ルニ二十日鼠デハ 腦内接種卜皮下接種トチ併施シタ組ノ中ノ 1 匹ガ早クモ第 3 日二於テ兩後肢ノ不全麻 痹キ顯ハシ．翌日ニ八全麻痹トナリ．余等ノ所謂飛行機型トナッタ。仍テ之レキ殺シ

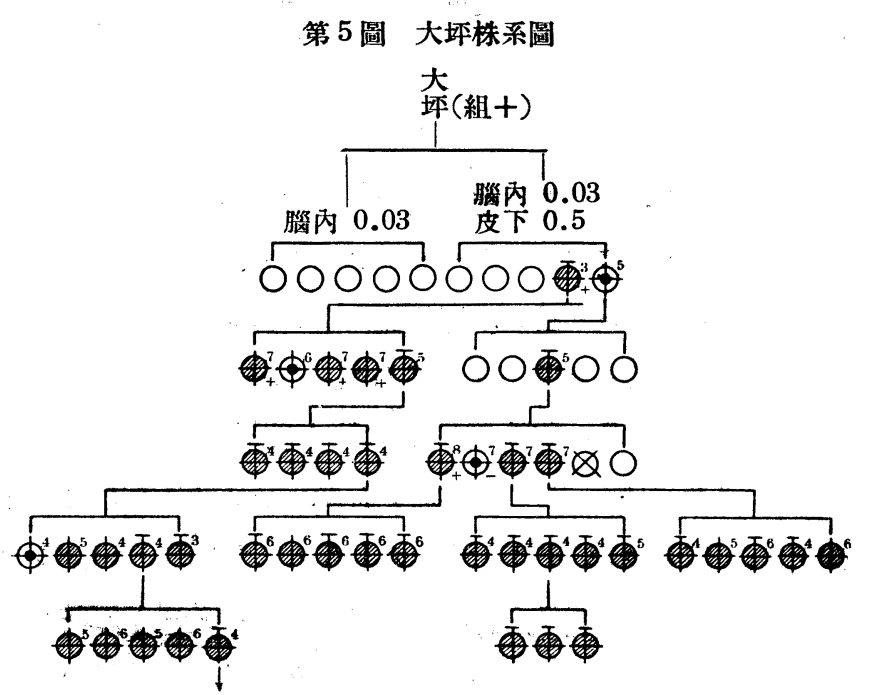
其腦キ以テ次代接種 ヨ行フタガ. 第 5 圖 二示入如ク. 容易ク 病毒 人培養ガ出來 タ。又同注組,他 1 匹八第 5 日二猬型 トナリ。柆日憋死七 ルキ發見シタノデ。 其腦子剔出シ。次代 接種尹行ツ夕。此腷 八死後八污染二基》 ト思ハレル極ク少數 
ノ雜菌テ混へテ居ツタガ. 第 2 代接種中二菌ハ消隇シ。第 4 代接種二至リ。二十日鼠 , 100\%が定型的症狀キ以テ罹患スルニ至ツタ。本例モ初代接種ヨり定型的症狀キ發 顯セシタタ例ノーツデアル。

本株祖病馬モ組織學的檢查二於テ嗅球. 前頭葉. 前中心廻轉. 尾狀核。「レンズ」核. 中心廻轉. 後中心廻轉. 視丘. 安門角. 後頭葉. 大腦脚. 腦橋. 延髓. 小腦及ビ頸髓 二輕度乃至中等度ノ血管周圍細胞浸潤及ビ「グリア」結節キ認メ。安門角二ハ著明ナル 出血ガアリ. 且商前頭葉. 前中心廻轉. 中心廻轉. 後中心伵轉. 後頭葉二八輕度乃至 中等度〉腦膜炎ガ見ラレタ。

私共八佐賀縣下，流行地二於テ。モゥ1頭腦炎患馬,腦キ採收スルコトタ得タ。三 養基郡北茂安村字中津隈. 草場某知育, 熊本縣產 2 葴牡馬デ. 昭和 11 年 8 月 30 日 , 未明ニ畜主が病アルチ發見シタ。同日正午えレタ檢診シタガ可ナリ重篤ナル定型症デ アッタ。同日夕刻血テ放ツテ殺シ. 直チ二解剖. 前 2 例卜同樣頭蓋腔內二於テ右大腦 牛球上前部/皮質キ切リ出シ.「グリセリン」中二投入シテ東京へ空輸. 9 月 1 日食監

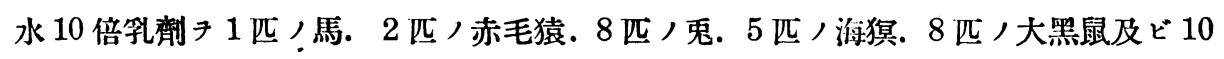
匹ノ二十日鼠二前 2 例卜同樣二接種シタ。然ル二馬. 猿. 鬼. 濉猽. 大黑鼠ノミナラ ズ. 二十日鼠モ亦 1 匹モ異狀キ呈スルモノガ出テ來ナイ。ソコデ其後二十白鼠接種フ 數回反復試乏。コレガ第メ用七タ二十日鼠，數ガ 224 匹二及ンダガ(内初代接種二供シ タ者 125 匹). 病毒, 分離八遂二成效シナカッタ。コレハドウモ病毒が輸途途中デ死 隇シタモノトハ考へラレヌ。思フ二病毒, 馬腦內ニ於ケル分佈ガ甚ダ不本等デァッテ 吾々ノ接種二供シタ部位が偶々病素タ含有シテ居ラナカツタノデアル乎(殊二發病) 極初期二殺シタカラ一曆ソウ云フコトガ考へラレル). 或八 Autosterilisation，篇入 二. 病毒八既二死隇シテ居ツタ第メデアラウ。但シ本馬ノ病氣ガ流行性腦炎二間違, ナイコト八其後ノ組織學的檢查二於テ前頭葉. 前中心廻轉. 尾狀核.「レンズ」核. 媵 中心廻轉. 安門角. 視丘。大腦脚。延䯣. 頸髓.胸髓二於テ血管周圍細胞浸潤及ビ「グ リア」結節站二前後中心廻轉二於テ腦膜炎ガ見ラレタカラ明デアル。何レニシテモ朝 霧株, 皆合, 如ク既二初代接種二於テ動物，100\%二定型庭尹.發七シメタ患馬ノアル 㥬ラ. 如何ニシテモ病毒, 分雄ノ出來ナカッタ者ノアッタコト八甚ダ注目スベキ事柄 デァル。ソレニ就テハ後学二述べル。

\section{北里大学四書館}




\section{第 II 章 分離病毒八總テ同一種ナルコト}

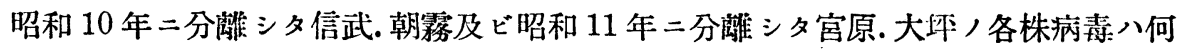
レモ同一ソモノ゙デァル乎。余等ハえレタ番二七ンガ䉆メ次ノ血清學的賽驗キ行フタ。

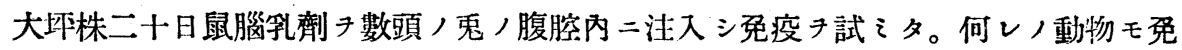
疫元株チ中和スル抗體キ大ナリ小ナリ產生シタガ. 取り分ケ 167 號鬼ガ最モ多量ノ抗 體含有セルチ知ツタノデ、コレチ以下記載スル所ノ各種賽驗ニ用ウルコトニシタ。 此血清ノ大坪株中和能力八第 1 表ノ通りデアルガ. 其检定法き述べルト.先ヅ Ringer

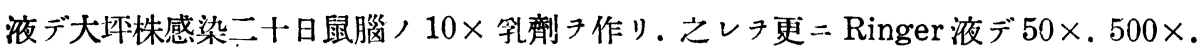
$5,000 \times .50,000 \times .500,000 \times$ 乳劑トナル如ク稀釋シ. 之レ二可檢血清 730 分間 $56^{\circ}$

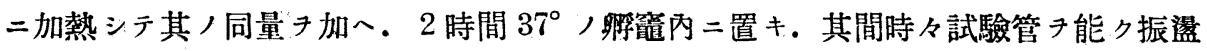

第 1 表 鬼 167 號抗大坪株血清效力檢定

\begin{tabular}{|c|c|c|c|c|c|}
\hline 毒濃度 & $20 \times$ & $100 \times$ & $1.000 \times$ & $10.000 \times$ & $100.000 x$ \\
\hline $\begin{array}{l}\text { 免疫後 } \\
\text { 盛 清 }\end{array}$ & $\mathbb{2}^{9} \mathrm{O} \bigcirc 0$ & $0^{11} \bigcirc 00$ & 0000 & 0000 & 0000 \\
\hline $\begin{array}{l}\text { 免疫前 } \\
\text { 血 清 }\end{array}$ & $70^{11} \bigcirc$ & $\mathbb{O}^{8} \mathbb{S}^{9} \not 2$ & 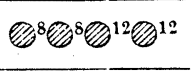 & $2^{10}{ }^{14} \bigcirc$ & ${ }^{13} \bigcirc \bigcirc 0$ \\
\hline 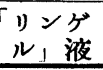 & $\mathbb{Q}^{6} \mathbb{U}^{7}$ & $60^{8}$ & $0^{6} \square^{8}$ & $Q^{7} \square^{8} \bigcup^{13}$ & $0^{12}{ }^{12} O 0$ \\
\hline
\end{tabular}

スル。次デ 3 時間室溫二靜置シ。此病毒血清混合液，0.03c.a 尹各 4 匹，二十日鼠， 腦內二接種シ。幾倍乳劑过感染免ル、ヤキ檢スルノデァル。そレト同時二上述各稀 澤病毒乳劑二免疫血清, 代り二. 免疫著手直前二採收三置キタル血清 $\left(30\right.$ 分 $56^{\circ}$ 加溫 $)$ キ加へタモノト. Ringer 液キ加へタ者トノ 2 種ノ對照尹置イタ。其加溫及ビ接種，

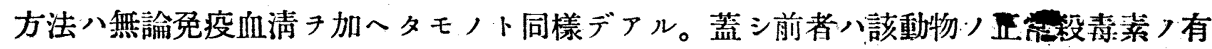

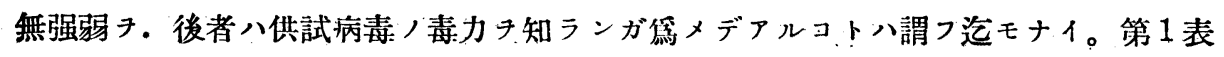
二示ス成績ニョレバ此動物ハ少量，正常殺毒素き保有シテ居ツタコトガ分ルガ. 免度 後, 血清ノ中和能力ト格段ノ差違ガアルカラ. 免疫後, 血清/病素中和作用八特異抗 體ノ產生二基クコト八毫モ疑, 存セザル所デァル。

立二於テ大坪。信武. 朝霧及ビ宮原ノ各株病毒が此血淸ニヨリテ中和セラル、狀況 ア比較シタ(賽驗法ハ血清ノ中和能力檢定法卜同樣)。其成績八第 2 表ノ通りデヌッテ 各株ノ間二少シ斗り差ガアルケレドモ。此位ナラバ各株トモモ同樣ニ中和サレタト見テ 差支へナイ。何トナレバ各供試病毒乳劑ノ毒力ガ固ヨリ完全ニ同一デナク. 又殘留病 毒量チ測定スル「レアンゲンツ」タル二十日鼠, 此病毒二對スル感受性ガ區々デァルか 
ラ.此位ノ差八致シ方ガナイ。サレバ 4 株ノ病毒八同一種ト斷ズベキデアル（本表中 二中尾株ト云フノガアルガ. えレニ就テハ第 VI 辡二於テ述べル)。

第 2 表 抗大坪株血清/他株馬腦炎毒中和試驗成績

\begin{tabular}{|c|c|c|c|c|c|c|c|}
\hline \multicolumn{2}{|c|}{ 株 名 濃 } & $20 x$ & $100 x$ & $1.000 \times$ & $10.000 \times$ & $100.000 \times$ & $1.000 .000 \times$ \\
\hline \multirow{5}{*}{$\begin{array}{l}\text { 抗寃 } \\
\text { 大一 } \\
\text { 坪六 } \\
\text { 株七 } \\
\text { 血添 } \\
\text { 清加 }\end{array}$} & 大 坪 & 11 & 000 & 0000 & 0000 & $0 \odot 00$ & \\
\hline & 信 武 & $\begin{array}{l}7 \\
0\end{array}$ & 1014 & 13000 & 0000 & 0000 & \\
\hline & 朝 蓩 & $\bigoplus 00$ & ช̊ำ & 8000 & 0000 & 0000 & \\
\hline & 宮 原 & $\stackrel{7}{0} \bigcirc \not 2$ & 000 & 0000 & 0000 & 0000 & \\
\hline & *中 尾 & $8 1 2 \longdiv { 1 2 0 0 }$ & 0000 & 0000 & 0000 & 0000 & \\
\hline \multirow{5}{*}{ 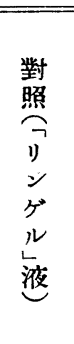 } & 大 坪 & 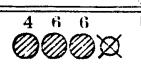 & 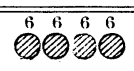 & 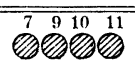 & 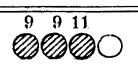 & ○11400 & 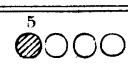 \\
\hline & 信 武 & 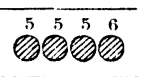 & 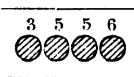 & ஜำ & ஜำ & 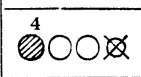 & 101500 \\
\hline & 朝 蓩 & $4 \longdiv { 4 }$ & $44^{456}$ & 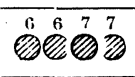 & ๑ $\mathrm{CO}$ & 7 212 & 0000 \\
\hline & 宮 原 & 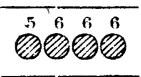 & 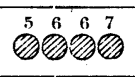 & 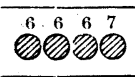 & $7^{7} 0^{10}{ }^{13}$ & 1314 & 0000 \\
\hline & *中 尾 & จ5 & ${ }^{5} 6^{6}{ }^{6}{ }^{7}$ & 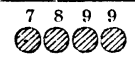 & $9^{1} 0^{10}{ }^{10}$ & ஜீன் & 11000 \\
\hline
\end{tabular}

*中尾株ニッイテハ後章デ述ベル

\section{第 III章＼cjkstart本「ヴュールス」ノ性筫}

\section{(1) 理化學的性質}

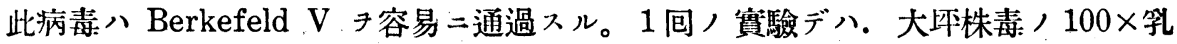
绂ハ此滤過器丹通過スルコトニヨリテ其毒力ガ約 $1 / 10$ 二減ジタコトチ見タ。其他ノ滤 過試驗八未了。

此病毒八他ノ神經親和性「ヴゥールス」ト同シク「グリセリン」耐性デアル。其他ノ物 理學的及ビ物理化學的性質站二各種理化學的作用二對スル抵抗力ハ未ダ調ベテナイ。

(2)病原作用

(1) 二十日鼠二對スル病原作用 常用實驗動物中本病毒二對シ最モ高度ノ感受性き 有スル者八二十日鼠デアル。潛伏期八接種量及ビ動物，個性ニヨリ一定デハナイガ. 今罹患二十日鼠,腦, $10 \times$ 乳劑ノ0.03c.c. 腦内接種スルト。最モ早キハ 2 日（コレ 八破格デァルガ). 遲キモ 6 日. 多クハ 4-5 日ノ潛伏期 以發病スル。其症狀八何 
，動物モ大體同樣デ．先ヅ動物ハ不活潑トナリ．眼䀞ガ何トナク不安キ示シ。毛キ

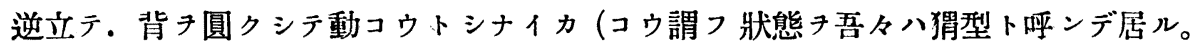
圖版 I /圖 1 及ビ圖 2 )。或ハ若シ 運步スルナラバ四肢チツマ立テ・チョコチココ然 トシテ步行スル。時トシテ初期精神發揚シ．盛二諸所テカケズリ迴ワリ．頻り二叫鳴 スルモノガァル。此種ノ者デハ次デ運動機興奮及ビ反射機興奮き顯ハスモノガ多イ。

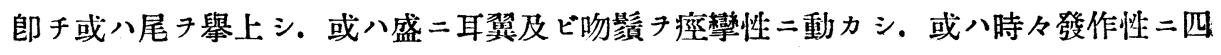

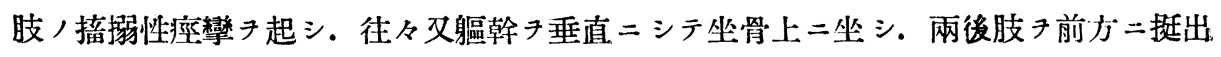
シ. 兩前肢キ以テ頻り二吻端キ摩擦シ。或ハえレチ上下二動カスコト恰モ「カンガル 一」チ觀ル樣デアル(「カンガルー」型一圖版 I，圖 3)。甚ダシキ二至りテハ提起七ル 軀幹丹後方二反掁シ. 第メ二後方二轉倒スルモノガアル。若シ動物キ $15-20 \mathrm{~cm}$,

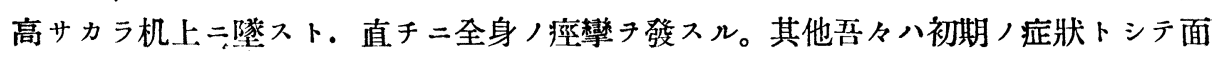
白イ顯象き發見シタ。郎チ未ダ完全二猬型ニモナラナイデ。一見健康，樣ニ見へルカ. 又ハ何ダカ違狀ガアリサウニモ思へルガ. 未ダ制然セヌ時期二. 試二蔦骨部/皮膚 拇指卜示指卜デ輕ク撮ムカ. 或八殊ニョイノ八.カクノ如ク皮覻き撮えナガラ. 動物

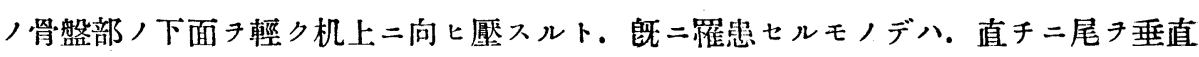
二擧上シ甚ダシキハえレォ脊柱ト本行二水本三シ。其尖端が耳間二達スルモノガアル。

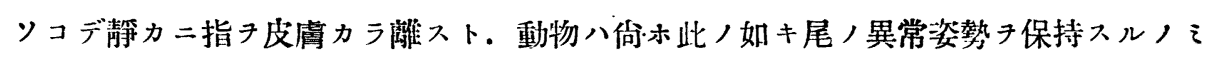
ナラズ全身不動トナリ．顏貌大不安ノ狀キ呈スル(圖版 I /圖 4)。此ノ如キコト $1-2$ 分間. 次デ常態二復シ. 再ビ活潑ニ步キ出ス。コレハ恐ラク反射機興奮ノ僬メ. 全身

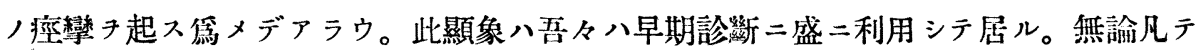

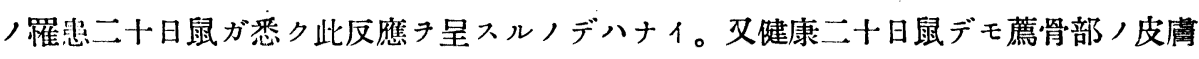
キッマそ，骨盤部キ稍 3 强ク机面二向ヒ壓下スルト往々尾擧上スルモノガアルガ. 此場合二八指キ碓スヤ。尾，位置キ常態二復シ。直チ二活潑二逃ゲ廻ルカラ區別スル。 コトガ出來ル。

猬型ト興奮型トキ問ハズ. 次デ起ルモノ八麼痹症狀デァル。時トシテ猬型症狀モ興

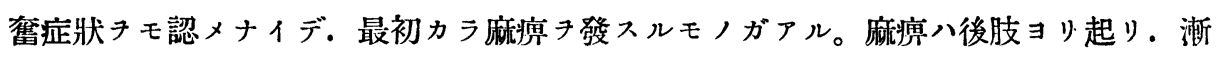
次前方二波及スルコトガ多イ。若シ兩後肢ガ完全二磨痹セル二. 前肢/機能ガ未ダ害 サレテ居ナイナラバ. 磨演七ル兩後肢キ本行二後方二提出シ. 健康ナル僚友卜共二盛 二運動シ. 頑ル奇異ナル觀 呈スル(飛行機型一圖版 1 ，圖 5 )。此磨㾇ガ前肢二波及 セバ步行八㓜論. 體位ノ變換サへモ出來ナクナリ・最後二八一見既二死セルガ如ク全 身不隨トナル。稀ニ八麻湢ガ先ジ前肢二顯ハレ. 次デ全身二擴ガルモノガアル(圖版 
III 圖 6 )。榮養八病初ヨリ衰へルモノガアルガ. 然ラザルモノモアル。然シ經過 2一

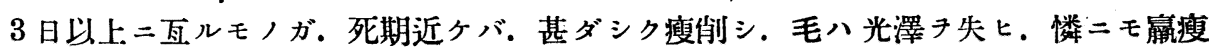
スルガ普通デアル。

經過ハ大抵八發病後 1-3 日デ斃レルガ. 稀ニハ 4-5 日生存スルモノガアル(最少 致死量二近イ分量キ接種サレタ場合二限ル樣ダ)。えレニ反シ發病後 24 時間以內. 甚 ダシキハ數時間デ斃レルモノモアル。明二罹患シタト認メ得タモノデ．治瘾シタ例ハ 未ダ一度モ見タコトガナイ。

毒力八病毒分離ノ初期ニ八左程高クハナイガ. 大凡 $12-3$ 代デ最高度二達シ．固定 スル。余等ノ 4 株ハ $0.03 \mathrm{cc}$ チ腦內接種スル場合. 通常 1 萬倍腦乳劑ハ 全部ノ二十日 鼠于製シ。時二ハ 10 萬倍. 加之 100 萬倍乳劑デ感染き起人動物ガアル。

整鼠, 腦子組織學的二檢查スルト。常二大腦, 諸部二血管周圍細胞浸潤及ビ「グリ ア」結節ガ見ラレ. 又屢了腦膜炎，併發七ルチ認メル(圖版 II /圖 1 及ビ圖 2 參照)。

（口）猿ニ對スル病原作用 第 I 章ニ於テ述ベタ如ク. 患馬/腦チ接種サレタ赤毛猿 4 匹中 3 匹八第 $5-7$ 日二於テ一過性,體溫上昇チ呈シタ以外. 何等ノ病徵テ顯ハス ニ至ラナカツタガ. 二十日鼠通過毒キ以テ試驗シテ見ルト。此動物ハ二十日鼠二次デ 感受性ノ高イ好實驗用動物 デァルコトチ知ツタ。罹患二十日鼠腦 $10 \times$ 乳劑 $1.0 \mathrm{c}$. 赤毛猿八腦内二注入スルト．第5一6日ヨリ體溫ガ上昇シ。其翌日八更二上昇スルガ. 次デ急二下降シ. 加之多クハ正常下體溫トナル。體溫ノ上昇シツ、アル間ハ單二食㗹 ノ減少キ認ムル二過ギナイガ. 體溫が下降シ始メルト．中心神經系ノ障碍二基ク症狀 ガ顯ハレテ來ル。郎チ最初ニ認ムルモノ八不安. 興奮. 全身ノ振額デ.コレハ大抵 1 日間デアル。次デ四肢, 磨淠ガ顯ハレル。麻痹ハ後肢ヨリ始マルコトガ多ク. 漸次上 昇スル。時二八膀脂麻痹ノ䉆又利尿失禁キ來スモノガアル。意識八最後迄變化シナイ

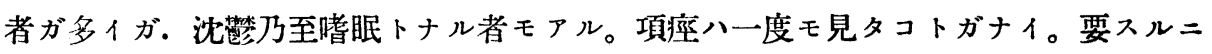
概シテ腦炎症狀ョリモ脊髓炎症狀ガ强イ。併シ何レガ强イカニョリテ．賽驗例キ大體 腦型卜脊髓型ト二別ケルコトガ出來ル樣二思へル。次二其各一例テ體溫表デ御眼二䜿 ケルコトニスル。第 5 圖猿 10 號八腦型. 第 6 圖猿 22 號八脊髓型デァル(猿 22 號二就 テハ佾圖版 III /圖 7 及ビ圖版 $\mathrm{V}$ ，圖 $1,2,3$ チ看ラレタイ)。

經過ノ最モ短イモノ八體溫が下降シ始メルト3-4 日デ彆レル。併シ 磨痹症狀ガ存 在スル儘經過ガ著シク遷延シ。最後二衰弱ニヨリテ幣レルモノガアル（1例ニテ八神

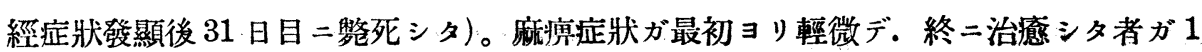
匹アッタ。又稀二八單二前述ノ如キ型ノ體溫上昇き起スノミデ．毫モ神經症狀き顯ハ 

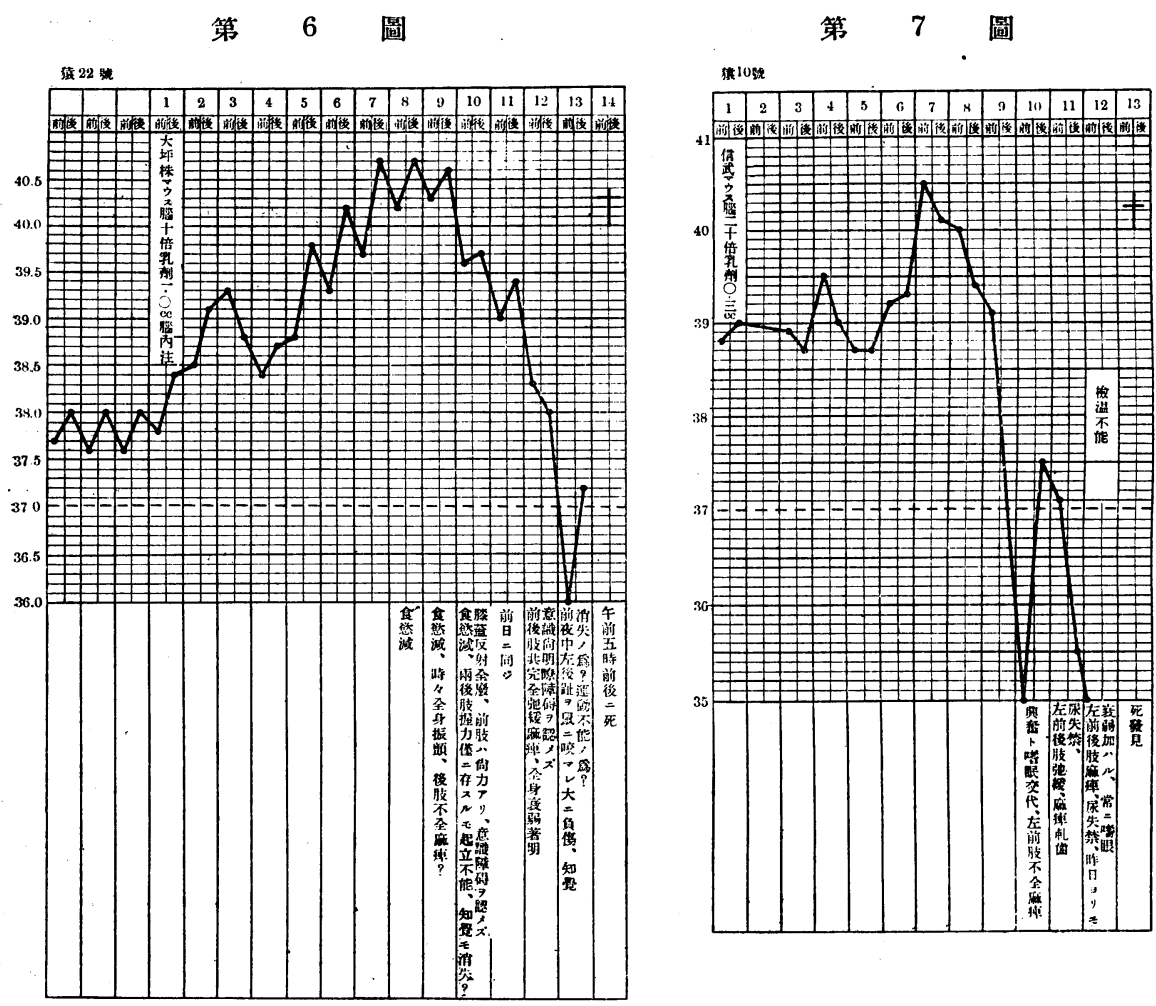

サズ．其儘健康キ持續スル者モアル。吾々ノ實驗例デハ。經過ノ著シク選延セシ者.

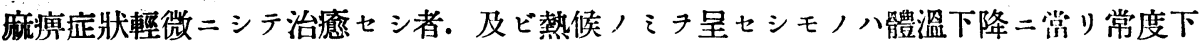
ニナルコトハナカツタ。常度下トナツタモノ八必ズ數日內二整レタ。

和猿 (Macaca fuscata) 八概シテ感染シ難イ樣デァル。併シ私共八信武株毒キ接種 サレタ 1 匹ノ和猿が定型的感染キ起シ。接種後第 11 日二整死シタ 1 例キ持ツテ居ル。

（ハ)馬二對スル病原作用 私共八昭和 10 年二信武株き 1 匹八馬二腦內接種シタガ. 體溫,上昇サへモ顯ハサズ. 全然無反應二終ツタ。昭和 11 年ニハ大坪株 6 匹ノ馬 二接種シタガ. 1 匹八中等度. 1 匹六極ク輕易. 1 匹八重篤ナル症狀キ呈シテ感染シ タ。本病毒 馬二對スル病原作用如何ハ最モ重要ナル問題デァルカラ. 煩キ厭ハズ. 是等 3 馬ノ病歷き述ベルコトニスル。

第 1 例 (第 8 圖參照)。被接種馬磐坂號. 稫島縣產. 7 歲.「アングロノルマン」雜種. 駻。昭和 11 年 11 月 26 日大坪株二十日鼠腦, 食監水 $10 \times$ 乳劑 20 c.a $\ni$ 左大腦牛球內 二注入。翌日體溫少シク上昇。食慈幾分減少. 次デ漸次解熱シテ第 4 日二八本溫度二 迄下タガ、第 5 日二至り又々體溫上昇シ始メ。第 6 日二八更二上昇シテ午後,體溫が 


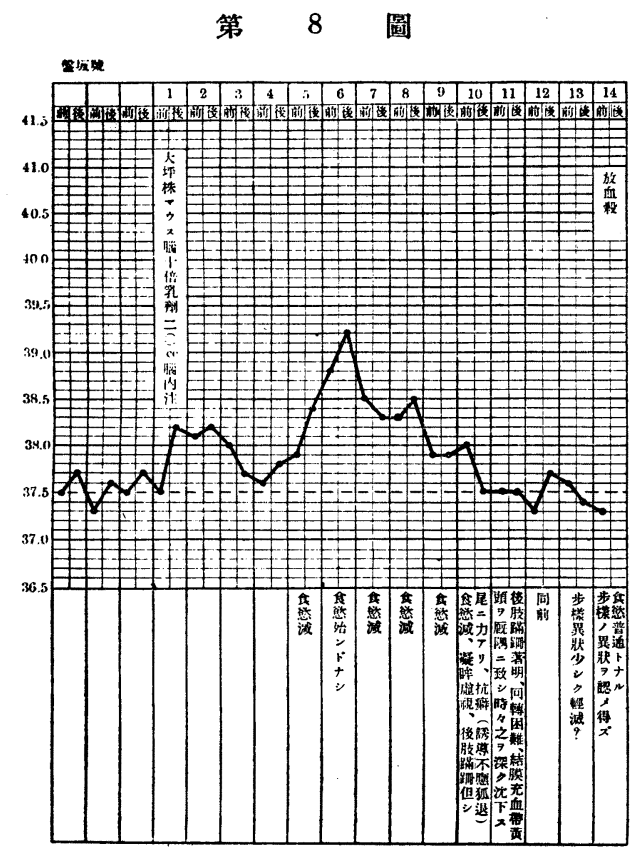

$39^{\circ} 2$ トナツタ。コレハ全經過中， 最高體溫デアッテ・爾後下降テタ ドリ。第 10 日二至ツテ本溫二復 シタ。發熱中ハ食慈減損ノ外特別 ノ異狀テ認メナカツタガ. 體溫ノ 平溫二復スルト同時二始メテ神經 系ノ症狀ガ顯ハレテ來タ。郎チ動 物ハ無表情ナアナザショ以テ何處 キ見ルトモナク一方キ凝視シテ居 ル。检診ノ感メ馬房ヨリ毫キ出サ ウトスルト，本素ト異リ，抗癖チ 顯ハシ. 誘導二順ハズ. 却テ狐退 スル。强テ牽キ出シテ常步セシメ ルト、後肢ガ蹋跚シ. 步幅ガ短縮 シ。小牛經, 廻轉ガ特二困難デア ル。速步デハ後肢ノ蹌踉ガ一虜顯著デアル。但シ尾ノ抵抗八毫モ減少ノ感ナク．腰覺 八寧口稍 、過敏デアル。又瞳孔ノ大サニ八異狀ナク．對光反應モ普通デアル。眼底檢 查ハ行ハナカッタカラ視神經弪頭ノ充血ノ有無八分ラナイガ. 結膜八體溫ノ低キ二拘 ラズ充血シテ居ル。柆日ハ大體同樣デアルガ. 頭キ常二馬房ノ通路ノ反對側ノ一隅二 向ケテ位置シ. 時々之キ深ク沈下スルノキ認メタ。併シ嗜眠ト稱スル程デハナク．舌

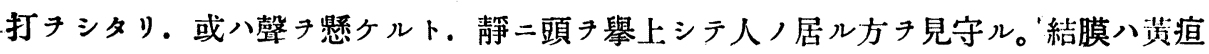
色丹帶ビテ來タ。第 12 日ハ同樣。第 13 日二八步樣ノ異狀が輕減シタ樣二思ハレタ。

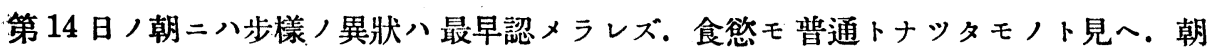
垌八全部食七畫シテ居ッタ。ドウャラ治痛スルラシイノデ. 同日午後放血ニヨリテ殺 シタ。中等症ト謂ツタノハ本例デアル。

剖檢スルト，軟腦膜ノ血管怒張. 腦實質割面二於ケル著明ナル血點形成. 腦脊髓液 ノ增量. 脾藏ノ滤胞ノ中等度ノ增殖. 心內膜下出血 認メタ。其他二此馬モ兩肺ノ後葉 ノ上面二涨萝性ノ高度ノ充血及ビ水腫ガアツタ。病馬信武號ノ腦キ接種サレタ乳駒玉 水號ノ肺ノ病變トヨ併七考へルナラバ. 馬腦炎毒ノ腦內接種ト肺ノ疾患卜ノ間二何等 カ因果關係ガアルノデハナカラウカ. 將來ノ研究, 參考迄二此事き記錄シテ置ク。肝 及ビ堅ニハ變狀ガナカツタ。組織學的所見ハ次表ノ通りデァル(圖版IV，圖 1 參照)。 
第 3 表 試驗馬盤坂號組織學的所見

\begin{tabular}{|l|l|l|l|l|l|l|l|l|l|l|l|l|l|l|l|l|l|l|l|}
\hline & 部 \\
位
\end{tabular}

注意 \pm 八當該變狀がアル樣デアルガ稍、磪實性ヨ缺ク婙アル標。

第 2 例 (第 9 圖參照)。被接種馬岩原號. 宮城縣產. 19 歲. 雜種. 騸。昭和 11 年 12

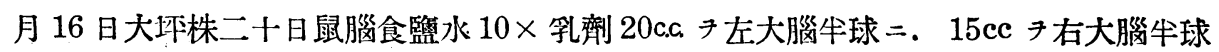
二注入。翌日體重上昇 $39^{\circ} 2$ 二至ッタガ. 其他ノ異狀チ認メヌ、翌日モ體溫少高ク $38^{\circ} 7$ 。

第 9 圖

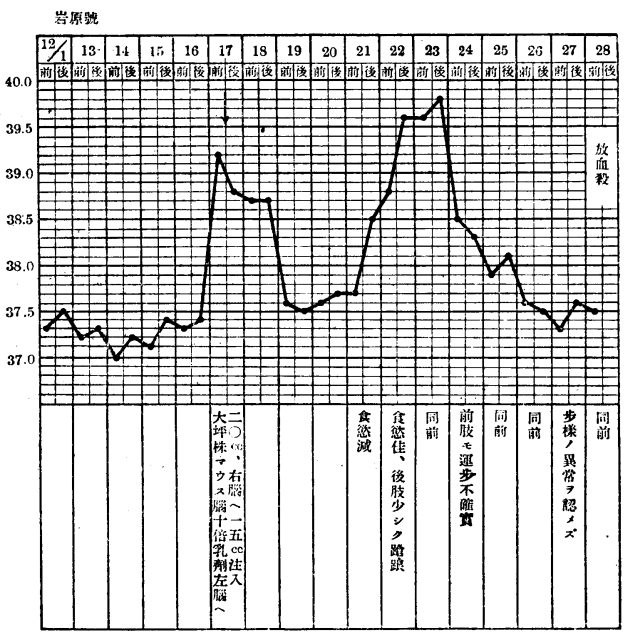

第 4 日二八本溫トナツタガ. 第 6 日コリ再ビ體溫上昇シ始メ。第 8 日ニ最高トナリ $\left(39^{\circ} 7\right)$. 次デ濑次 下降シ。第 11 日二平溫トナッタ。 第 7 日二八後肢ノ運步少シク蹌踉 トナリ。第 9 日ニ八前肢ノ邁動モ 確實サチ失ヒテ恰モ探ルガ邚キ步 樣キナス二至ツタ。然ル二第 12 日 ニナルト．此ノ如キ步履, 異狀八 最早胃ラレナクナッタ。第13日放 血シテ殺ス。食慈八體溫, 上昇シ 始メ夕第 6 日二於テ著シク減損シ タガ．翌日ニ八再ビ恢復シ。爾來最後迄佳良デアッタ。本例ノ主ナル症狀ハ他ノ 2 例 卜同型,體溫上昇卜輕微ナル步法ノ異狀ノミデアル。郎チ本例八其症狀丈ケデ謂フナ ラバ. 3 例中ノ最輕症例デアル。

殺後直チニ剖檢シタガ. 軟腦膜八溷濁充血シ．左右中心廻轉ヨリ始マリ．後方へ絔 $7 \mathrm{~cm}$ 二達スル帶綠黃白色ノ索狀膠樣浸潤ガアッタ。ソレカラ左右ノ兩大腦牛球內二

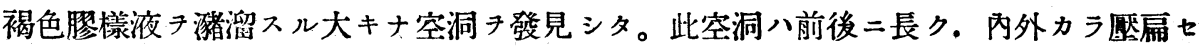


ラレテ其前頭斷面八紡銓形チナシテ居ル。左右トモ其位置. 形狀及ビ大サガ略 、同一 デ共二前後經約 $7 \mathrm{~cm}$. 上下經最モ廣イ處デ約 $3 \mathrm{~cm}$. 內外經中央ノ最廣イ處デ約 $7 \mathrm{~mm}$. 其項線八大腦牛球ノ表面下約 $5 \mathrm{~mm}$ 八處ニアッラ概ネ之レト本行シテ居ル。空洞ノ周、 圍八綠色き呈シ。「フォルマリン」固定後「ビリルービン」反應き檢シタノ二弱陽性デア ツタ。此空洞／位置八左右共病毒注射點卜一致七ル點カラ考へルト．注射ノ際毛細管

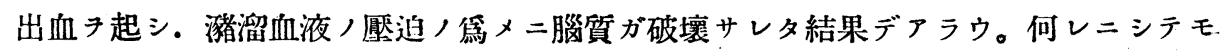
カ、ル偉大ナル器質的變狀ガ腦髓中二存スルニモ拘ラズ. 動物ハ左程顯著ナル官能障 碍キ表ハサナカッタコトハ全ク豫想ノ外ト謂ハネバナラヌ。其他ノ變狀トシテハ中心 廻轉部二於ヶル硬腦膜ノ石灰沈著. 腦割面ノ著明ナル血點形成。心內膜ノ出血及ビ心 筋, 輕度, 溷濁. 中等度, 感染脾. 肉营冠肝. 腎臟, 輕度, 溷濁腫脹。淋巴腺, 輕度 ノ隨樣腫大デアッタ。

組織學的所見ハ次表ノ通りデ．概シテ强クハナカッタ。併シ本例デハ其程度ハ必シ モ甚ダ强クハナイガ. 到ル處二出血ガアッタ。彼/空洞形成卜謂七. 此組織的出血卜

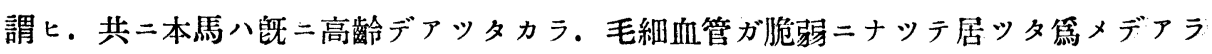
ウ。少ホ奇異二感ゼラレタコトハ自然感染馬デモ. 實驗的感染馬デモ。組織學的變狀 八一般二尾狀核.「レンズ」核. 視丘二强ク顯ハレルニ拘ラズ。本例デ八是等ノ部位ハ 他ノ部ヨリモ寧口變狀ガ弱カッタ。

第 4 表 試驗馬岩原號組織學的所見

\begin{tabular}{|c|c|c|c|c|c|c|c|c|c|c|c|c|c|c|c|c|c|c|c|c|c|c|}
\hline 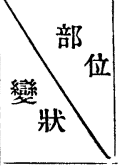 & 球 & $\mid \begin{array}{l}\text { 前 } \\
\text { 頭 } \\
\text { 葉 }\end{array}$ & $\begin{array}{l}\text { 後 } \\
\text { 前 } \\
\text { 頭 } \\
\text { 葉 }\end{array}$ & $\begin{array}{l}\text { 中 } \\
\text { 前 } \\
\text { 頭 } \\
\text { 葉 }\end{array}$ & $\begin{array}{c}\text { 下 } \\
\text { 前 } \\
\text { 頭 } \\
\text { 葉 }\end{array}$ & $\begin{array}{l}\text { 前 } \\
\text { 出 } \\
\text { 唒 } \\
\text { 轉 }\end{array}$ & 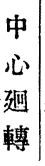 & $\begin{array}{l}\text { 後 } \\
\text { 中 } \\
\text { 徊 } \\
\text { 轉 }\end{array}$ & $\begin{array}{l}\text { 線 } \\
\text { 狀 } \\
\text { 體 }\end{array}$ & $\begin{array}{l}\text { 尾 } \\
\text { 狀 } \\
\text { 核 }\end{array}$ & $\begin{array}{l}\neg \\
\nu \\
\check{2} \\
\grave{2} \\
\text { 核 }\end{array}$ & $\begin{array}{l}\text { 安 } \\
\text { 門 } \\
\text { 角 }\end{array}$ & 兵 & $\begin{array}{l}\text { 齫 } \\
\text { 頂 }\end{array}$ & $\begin{array}{l}\text { 後 } \\
\text { 頭 } \\
\text { 畐 } \\
\text { 轉 }\end{array}$ & $\begin{array}{l}大 \\
\text { 腦 } \\
\text { 脚 }\end{array}$ & 腦 & 小 & 髓 & 體 & 胸 & 腰 \\
\hline 血箇周圍胞浸潤 & + & + & $\begin{array}{c}+1 \\
1 \\
+H\end{array}$ & $+t$ & + & + & $+t$ & + & ++ & + & + & + & + & + & \pm & + & + & + & +4 & + & + & + \\
\hline 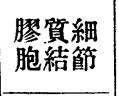 & + & \pm & $\begin{array}{r}+ \\
+t \\
+\end{array}$ & \pm & + & + & $H$ & $1+$ & $\begin{array}{c}+ \\
1 \\
+t\end{array}$ & $\begin{array}{c}+ \\
1 \\
+t\end{array}$ & + & + & + & + & \pm & + & $H$ & + & + & + & $+t$ & + \\
\hline 出 血 & + & + & H+ & ++ & + & + & $\begin{array}{c}+ \\
+t \\
+\end{array}$ & \pm & - & \pm & - & + & \pm & + & + & - & - & - & - & + & -1 & - \\
\hline 腦膜炎 & \pm & \pm & + & $+t$ & + & + & - & + & 1 & 1 & 1 & 1 & 1 & + & \pm & + & + & \pm & \pm & \pm & \pm & \pm \\
\hline
\end{tabular}

第 3 例 (第 10 圖參照)。えレガ最重症例デアル。被接種馬啓武號. 北海道座.「ペルジェ ロン」雜種. 8 ケ月/幼牡駒。昭和 12 年 1 月 14 日大坪株二十日鼠腦食監水 $10 \times$ 乳劑! 10c.c.ラ左大腦牛球內二注入。第 6 日迄體溫殆ンド正常。第 7 日ヨリ體溫上昇シ始メ。 第 9 日最高二達シ $\left(39^{\circ} 8\right)$. 爾後急二下降シ. 第 11 日ニ八既二平溫トナル。第 8 日食僽 


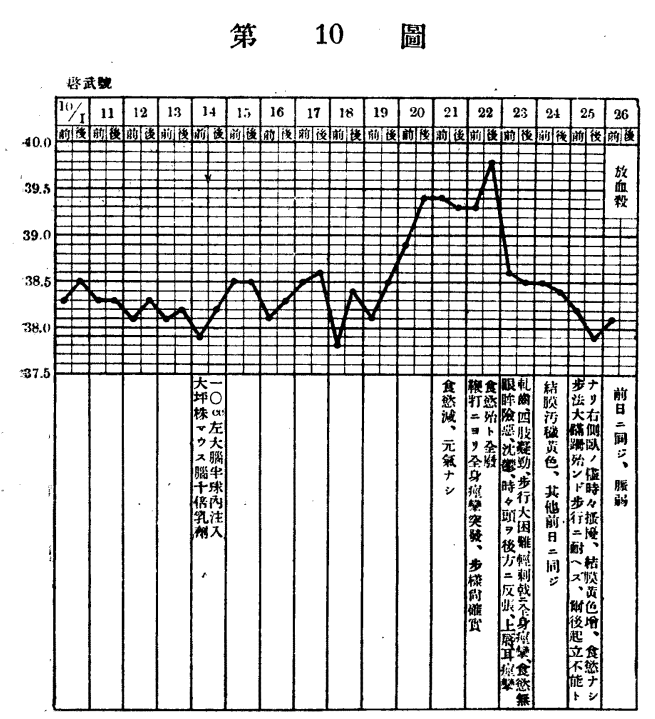

減退. 元氣衰つ。第 9 日步樣フ检セ ンガ第入馬房ヨリ毫キ出サウトシタ ガ. 步行キ厭七。誘導二應ジナイ， デ．解部二、鞭キ加へルト．忽チ劇 烈ナル全身ノ痙杽發シ. 終二地上 二倒し約 5 分 ニシテ沈静シ起立シ タ。步マセテ見ルト步樣八劣唯實デ アッタ。第 10 日眼䀞著シク險惡。一 方キ凝視・常二頭ノ前面丹擘壁二壓 抵シテ起立シ。時々頭き上後方二反 張スルト同時二上原及ビ耳采が揞搦 シタ。又頻り二軋齒スルキ見タ。腰 覺過敏. 鷹骨部丹指壓スルト急突二

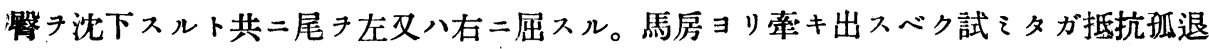
シ容易二誘導二順ハナイ。毣部キ後方ヨリ押シ强イテ運步セシメルト四肢ノ運動甚ダ シク凝勁. 腕節及ビ飛節八允分二屈折シナイ。食怹全廢. 精神幾ラカ溷濁セルモノ、 如ク見へタ。第11日八前日ト大體同樣デアルガ. 四肢ノ凝勁ノ度增加ノ感がアリ. 結膜少シク充血シ。污穢黄褐色。第 12 日精神仰壓著明. 常ニ頭チウナ垂レ. 眼タ牛

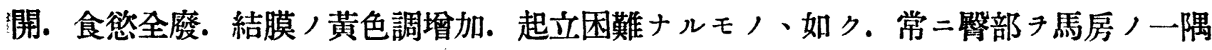

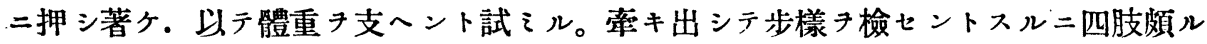
蹌踉トシテ殆ンド步行ニ耐へズ.人力ノ補助テ受ケテ輕フジテ運步シタガ. 終二地上 ニ倒レタ。而シテ一旦八起立シテ(人力ノ補助ニョリ)噼二歸ツタガ.ヤガテ起立全ク 不能トナリ.右側テ下ニシテ常二横卧位チ保チ.時々四肢キ前後二動カシテ搔損スル。 第 13 日モ同樣。橫臥位ニテ檢スルニ前肢八他働的屈伸二對シテ殆ンド抵抗テ感セズ. 後肢ハコレニ反シテ硬固 (Rigidität) デアル。脈搏弱ク．遠カラズ整死き免レヌト認メ タノデ、午後放血シテ殺シタ。

殺後直チ二解剖シタ。剖检所見八軟腦膜及ビ腦賽質ノ立血. 心內膜ノ出血站二心筋 八溷濁. 左肺中葉下端二於ヶル $7 \times 5 \mathrm{~cm}$ 人無氣肺形成. 右肺, 沈噇性肺炎. 全身淋 巴腺ノ髓樣腫大デアツタ。

組織學的所見ハ次表ノ通りデ．本例八其症狀ガ甚ダ重篤デアッタダケニ中心神經 系二於ヶル病變モ亦强度デアル(圖版 IV ノ圖 2 參照)。 
第 5 表 試驗斯啓武號組織學的所見

\begin{tabular}{|c|c|c|c|c|c|c|c|c|c|c|c|c|c|c|c|c|c|c|}
\hline 狀 & 球 & $\begin{array}{l}\text { 前 } \\
\text { 頭 } \\
\text { 葉 }\end{array}$ & $\begin{array}{l}\text { 前 } \\
\text { 中 } \\
\text { 心 } \\
\text { 迴 } \\
\text { 轉 }\end{array}$ & $\begin{array}{c}\text { 中 } \\
\text { 心 } \\
\text { 殉 } \\
\text { 轉 }\end{array}$ & $\begin{array}{l}\text { 後 } \\
\text { 中 } \\
\text { 心 } \\
\text { 呬 } \\
\text { 轉 }\end{array}$ & $\begin{array}{l}\text { 線 } \\
\text { 狀 } \\
\text { 體 }\end{array}$ & $\begin{array}{l}\text { 尾 } \\
\text { 狀 } \\
\text { 核 }\end{array}$ & $\begin{array}{l}\text { ᄀ } \\
\text { У } \\
\text { ズ } \\
\text { 核 }\end{array}$ & $\begin{array}{l}\text { 安 } \\
\text { 門 } \\
\text { 角 }\end{array}$ & 乒 & $\begin{array}{l}\text { 後 } \\
\text { 頭 } \\
\text { 㻁 } \\
\text { 轉 }\end{array}$ & $\begin{array}{l}\text { 大 } \\
\text { 腦 } \\
\text { 脚 }\end{array}$ & 橋 & 腦 & 醚 & $\begin{array}{l}\text { 頸 } \\
\text { 鰖 }\end{array}$ & 䯕 & 腰 \\
\hline $\begin{array}{l}\text { 管周圍 } \\
\text { 沺胞浸潤 }\end{array}$ & + & $\begin{array}{c}+ \\
1 \\
++\end{array}$ & $\begin{array}{c}+ \\
1 \\
+t\end{array}$ & $\begin{array}{c}+ \\
1 \\
++\end{array}$ & $H$ & $\stackrel{++}{1+H}$ & $\begin{array}{c}+ \\
++\end{array}$ & $\underset{1}{H}$ & + & H & $\begin{array}{c}+ \\
+t\end{array}$ & $\stackrel{+1}{+4}$ & $\stackrel{+t}{\mathrm{H}}$ & $\begin{array}{l}+ \\
+\end{array}$ & + & + & + & $t+$ \\
\hline $\begin{array}{l}\text { 脉質細 } \\
\text { 胞結触 }\end{array}$ & + & + & $t+$ & $t+$ & $\begin{array}{c}H \\
1 \\
H\end{array}$ & $H$ & $t+$ & $\begin{array}{c}++ \\
1 \\
+H\end{array}$ & + & H & \pm & $H$ & H & + & + & + & $\underset{1}{H}$ & $\begin{array}{l}++ \\
\text { H+H }\end{array}$ \\
\hline 出 血 & - & - & - & - & - & - & - & - & - & - & - & - & - & + & - & - & + & - \\
\hline 腦膜咨 & $\begin{array}{c}+ \\
1 \\
+\end{array}$ & + & $+t$ & tt & & \pm & $/$ & 1 & I & I & + & \pm & \pm & + & \pm & \pm & \pm & \pm \\
\hline
\end{tabular}

劣又本例デ八嗅球. 視丘. 安門角. 尾狀核. 小腦. 頸髓. 腰髓中二。二十日鼠腦內: 接種ニヨリテ・接種病毒が證明サレタ。殊二興味アルハ蛋二中心神經系ノそナラズ。 末梢神經 (正中神經及ビ脛骨神經) 中二病毒ノ存在き證明シタコトデアル。馬ノ實驗的; 腦炎二於ヶル病毒ノ體內分佈二就テハ近日稿テ改メテ詳細報告スル積りデアル。

接種試驗ノ成績二由テ之レテ見ルト. 馬八二十日鼠ヤ. 赤毛猿ヨリモ此病毒二對ス ル感受性ガ弱イ。或ハ感受性キ有スル個體ガ比較的少イト謂ツタカ丶万滴當デアルカモ 知レヌ。私共ハ後文論述スル樣二. 此「ヴ 體卜認メルモノデアルガ. ソウスルト此事賽八蜜口同症／疫學的所見二一致スル樣二 思へル。但シ接種陰性馬 3 頭中 1 匹八第 8 日二於テ體溫 $38^{\circ} 6$ トナリ.1匹八第 6 日二 於テ $38^{\circ} 5$ トナツタ。何レモ唯 1 日丈ケデアツタガ.えレガ觀察中ノ最高體溫デアッタ。 接種陽性馬；體溫上昇，模樣二鑑レバ或ハえレハ最輕感染ニョル反應熱デアッタカモ 知レヌ。記シテ將來, 研究, 參考二供へル。

(二)鬼. 海猽及ヒ大黑鼠二對スル病原作用 多數, 鬼. 游猽及ビ大黑鼠，腦內二出 來ル丈ケ大量二此病毒キ注入シテ見タガ. 未ダ 1 匹モ悎二腦炎二罹患シタト認メ得タ モノ二遭遇シナイ。本病毒八是等，動物ニ對シテハ病原作用ガナイ樣二思へル。

\section{第 IV羊 本病毒八吾邦ノ馬ノ流行性腦炎ノ原因體デアル}

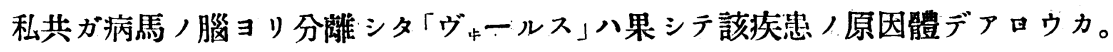

私共ハえレチ確メル一手段トシテ陸軍獸醫學校病馬廠二慗留中， 2 頭，腦炎恢復

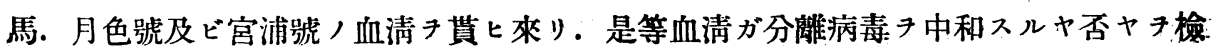


シタ。月色號ノ血清ハ殆ンド中和能力ォ示サナカツタ。宮浦號ノ血清八毒力一萬ノ病 毒 (罹患二十日鼠腦, 1 萬倍乳劑 $0.03 \mathrm{c}$. 腦內接種サレタ二十日鼠ノ全部が罹患整死

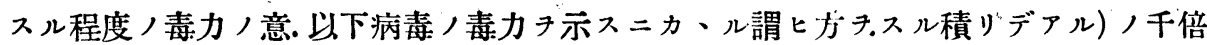
乳剂迄チ中和シタガ. 百倍乳剂入中和シ得ナカツタ。非腦炎馬ノ中二モ其血清ガ此程 度ノ中和作用キ呈スルモノガアル樣ダカラ（三田村等(14) 八夏期腦炎毒 此程度. 加之 更二强ク中和スル血清ョ有スル馬ノ多數二存在スルコトチ報告シタ). 本馬ノ罹患前 ノ血清ノ中和能力フ檢シ得ルニアラザル限リ．此實驗ハ遂二無意味ニ終ツタ。ソレニ モ拘ラズ. 私共八此病毒コソ吾邦ノ流行性馬腦炎ノ原因體ナリト確信スル。其理由ト スル所八

(1) 組織學的所見ヨリ見テ悎カ二腦炎二罹ツタト認メ得ル 5 頭ノ馬，丙 4 頭ヨリ此 病毒ガ分離サレタコト。

（2）以上 4 頭，內 3 頭二於テ八既二其初代接種動物，全部及ハ一部ガ定型的症狀 上テ發症シタコト。

(3)馬二接種スルト自發腦炎卜同樣ナル疾患タ起スコト。 論者或ハ謂ハン．上上ノ理由丈ケデ。コレチ吾邦／流行性馬腦炎／原因ト斷定スル ニ八其論據劣ホ薄弱デハナイカ。コトニヨレバ. 實驗二用ヒタ二十日鼠ノ中二. 其腦 內二非活㗢性トナツテ居ル二十日鼠固有ノ腦炎毒チ保有スルモノガアッテ・此動物， 腦內二多量, 異物ガ注入サレタ篇メ二. 潛医病毒八俄カ二賦活サレ.コレチ吾々ガ健 康二十日鼠,腦內二於テ培養シタノデハナイカ. 殊二第 1 例信武號, 腦キ以テスル實 驗二於テ乳駒玉水號八臨林的ニモ組織學的二モ腦炎ガ證明サレナカツタニモ拘ラズ. 其腦キ接種サレタ二十日鼠ヨリ同一病毒が分離サレタ如キハ一層此感キ染カラシムル モノガアルト。此抗議ハ一應ハ尤デアル。併シソウスルト朝霧號ノ腦キ接種サレタ 10 匹ノ二十日鼠ガ全部添フテ定型的症狀キ呈シテ罹患シタコトト，反對二昭和 11 年度 , 第 3 例病馬カラ病毒丹分雄スベク. 二百數十匹人二十日鼠ガ其腦內二馬. 又八二十 日鼠ノ腦物質丹注入サレタニモ拘ラズ。1 1 匹モ罹患スルモノ、ナカツタ事實ハ之レチ 如何二說明スルカ(其他私共八病馬ノ腦キ接種サレ.及、分雄病毒き接種サレタニモ拘

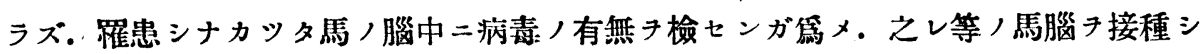

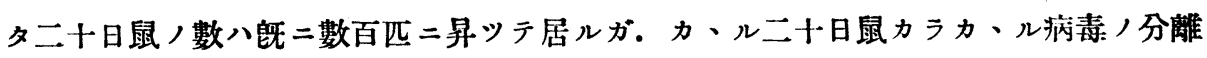
サレタ例ハーツモナ1)。えレチ單二偶然ノ結果ナリト謂へバソレ迄デアルケレドモ。 ソレハ吾人微生物病學徒, 常識カラハ.トテモ考へ得ラレヌ處デアル。サレバ私共ハ 此「ヴ.ールス」ハドコ汽モ病馬，腦内二存在シテ居ツタモノ，換言セバ流行性馬腦炎 
ノ原因體ナリト斷定スル。序ナガラ此病毒ハ先年アメリカデ Theiler ${ }^{(15)}$ ガ自然二腦脊 髓炎二罹ツテ居ル二十日鼠カラ分離シタ病毒トモ. 將タ又同ジクアメリカデTraub ${ }^{(16)}$ ガ外觀健全ナル二十日鼠,腦カラ分離シタ腦炎病毒トモ一致七ヌ。何トナラバ前者八 rhesus 猿ニハ病原作用ナシト謂七。後者ハ淮猽二對シ甚名高度/病原作用ガアルト 謂ツテ居ルカラデアル。

\section{第 V 章 馬腦炎病毒卜夏期腦炎病毒卜ノ關係}

私共カ腦炎患馬ヨリ分灕シタ病毒, 各種賽驗用動物二對スル病原作用. 郎チ感受性 キ有スル動物ノ種類及ビソレ等が罹患シタ場合/症狀. 組織學的變狀ハ人間ノ夏期腦 炎病毒ノソレト全ク一致スル。泫二於テ私共八是等兩種病毒, 異同チ免疫學的二調べ ル必要キ感ジ, 次ノ實驗キ行フタ。

\section{A. 血清學的試驗}

(1) 抗夏期腦炎毒血清, 馬腦炎毒中和試驗

先ヅ第一二夏期腦炎毒ヨ以テ兑疫サレタ動物ノ血清が馬腦炎毒き中和スルヤ否やキ 檢シタ。其成績八第 6-8 表ノ通リデァル。此內第 6 表ト 7 表ハ是等兩毒ガ同一血淸 (非稀釋) ニョリテ中和セラル、最大量ノ比較. 第 8 表八略 ? 同樣ノ毒力ョ有スル兩毒 ノ同一量キ中和スルニ要スル血清ノ最少量ノ比較デアル。其「テクニックリハ第 II 章二 於テ兑疫血清ノ效力檢定二就テ述べタ所ト同一デアル。而シテ之レニ用ヒタ血清ト 夏期腦炎毒「カリニーナ」株ト八三田村博上ヨリ分與ナ受ケタ．泫二其好意二對シ謝意 э表スル。

是レ等ノ表二於テ見得ラル、如ク抗夏期腦炎毒血清八馬腦炎毒き夏期腦炎毒ト同程 度二中和スル。

第 6 表 抗夏期腦炎毒血清 7 以テ夏期腦炎毒及ビ馬腦炎毒中和試驗成綪(其 1)

\begin{tabular}{|c|c|c|c|c|c|c|}
\hline \multicolumn{2}{|c|}{ 毒濃度 } & $10 \times$ & $100 x$ & $1.000 \times$ & $10.000 x$ & $100.000 x$ \\
\hline \multirow{2}{*}{$\begin{array}{l}\text { 血 } \\
\text { 清 } \\
\text { 加 }\end{array}$} & 素 & 11000 & 0000 & 0000 & 0000 & 0000 \\
\hline & $\begin{array}{l}\text { 馬 } \\
\text { 毒 }\end{array}$ & ${ }^{11}{ }^{12} \bigcirc O$ & 0000 & 0000 & 0000 & 0000 \\
\hline \multirow{2}{*}{$\begin{array}{l}\text { 對 } \\
\text { 照 }\end{array}$} & $\begin{array}{l}\text { 毒 } \\
\end{array}$ & $\vartheta^{5} \oslash^{5}$ & $0^{5} 0^{6}$ & $\vartheta^{6} 0^{5} 0^{7}$ & $\vartheta^{9} \bigoplus^{11} \bigoplus^{15}$ & 000 \\
\hline & 馬 & $\square^{6} \bigoplus^{6}$ & $0^{6}$ & $0^{9} \oslash^{14}$ & $\vartheta^{13} \vartheta^{8} \vartheta^{10}$ & 0000 \\
\hline
\end{tabular}

使用血清: 「カリニーナ」馬(白金)血清（三田村博士ョッ分與 ヨ受ク）

人 毒:「かリニーナ」株

馬 毒：大坪株 
第 7 表 抗夏期腦炎毒血清 7 以テ夏期腦炎毒及ビ馬腦炎毒中和試驗成績(其 2 )

\begin{tabular}{|c|c|c|c|c|c|c|}
\hline \multicolumn{2}{|c|}{ 毒濃度 } & $20 \times$ & $100 x$ & $1.000 \times$ & $10.000 \times$ & $100.000 x$ \\
\hline 血 & 食 & $0^{12} \bigcirc$ & $0^{8} \bigcirc$ & 000 & 000 & 000 \\
\hline 加 & 馬 & 000 & $0^{10} \bigcirc \bigcirc$ & 000 & 0.00 & 000 \\
\hline 對 & 金 & $Q^{5} Q^{6}$ & $\square^{6} \square^{6}$ & $\square^{6} \mho^{6}$ & $\mathscr{Z}^{6} \square^{5}$ & $0^{11} 0^{11} \bigcirc$ \\
\hline 照 & 馬 & $Q^{8} \not$ & $\mathscr{Q}^{8 \times} \mathscr{0}^{7}$ & $\bigotimes^{9} \mathscr{Q}^{i} \not$ & $Q^{9} Q^{7}$ & $0^{16} \bigcirc \quad O$ \\
\hline
\end{tabular}

使用血清:「「リニーナ」山羊( 9 號)血清(三田村博士ョリ分與习受ク)

人：毒：「カリンニーナ株

馬 毒：大坪株

第 8 表 抗夏期腦炎毒血清 7 以テ夏期腦炎毒及ビ,馬㺦炎毒中和試驗成績(其 3 )

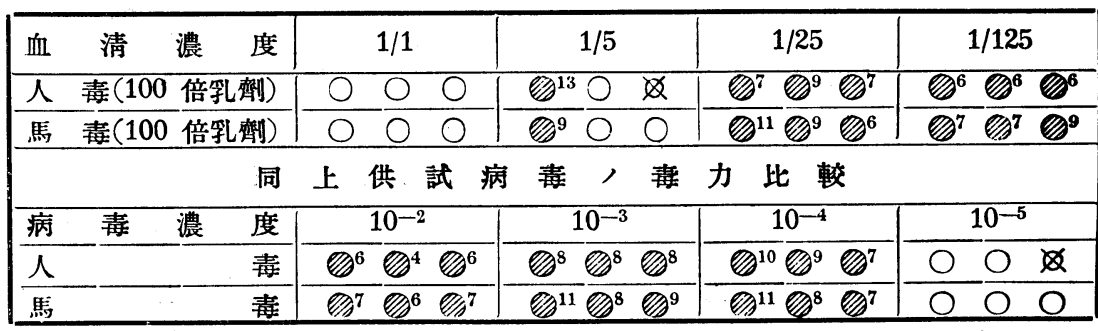

使用血清: 「カリニーナ」山羊 $(9$ 號)血清(三田村博士ヨリ分興 ヨ受ク)

人 毒: 「カリニーナ」株

馬 毒：大坪株

(2) 抗馬腦炎毒血清, 夏期腦炎毒中和試驗

私共ハ抗夏期腦炎毒血清ガ馬腦炎毒き夏期腦炎毒卜同程度二中和スルコトナ見タガ 然ラバ反對二抗馬腦炎毒血清八 夏期腦炎素二對シテ如何ナル作用キ呈スルヤキ檢シ タ。實驗方法八前項卜同樣. 使用血淸八第 II 章二述ベタ鬼 167 號デアル。其成績ハ第 第 9 表 抗大坪株血清, 人腦炎毒中和試驗成綪

\begin{tabular}{|c|c|c|c|c|c|c|c|}
\hline \multicolumn{2}{|c|}{ 株. 名 ${ }^{\text {病表 }}$} & $20 \times$ & $100 x$ & $1.000 \times$ & $10.000 \times$ & $100.000 \times$ & $1.000 .000 \times$ \\
\hline \multirow{3}{*}{$\begin{array}{l}\text { 垫兔 } \\
\text { 梅突 } \\
\text { 䘏添 } \\
\text { 清加 }\end{array}$} & 大 呠 & $11^{12} 14$ & 11000 & 0000 & 0000 & 0000 & \\
\hline & $\begin{array}{l}\text { カリ } \\
\text { ナ }\end{array}$ & $8{ }^{111416}$ & 14000 & 0000 & 0000 & 0000 & \\
\hline & $\begin{array}{l}t .1 \\
ル-1 \pi\end{array}$ & $6^{6} \overbrace{}^{6}{ }^{7}$ & $\frac{6}{7} 7^{7}$ & $7^{7} 7^{7} 7^{7}$ & 88 & 9000 & \\
\hline \multirow{3}{*}{ 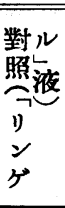 } & 大 呠 & $\overline{4} \operatorname{4}^{6}{ }^{6}$ & 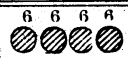 & 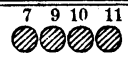 & ஜำ11 & $13^{14}$ & Øூ000 \\
\hline & $\begin{array}{l}\text { カリ } \\
\text { ナ }\end{array}$ & 455 & 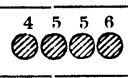 & 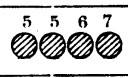 & 77 77889 & $1300 \otimes$ & 0000 \\
\hline & $\begin{array}{l}セ \text { V } \\
\text { UーA }\end{array}$ & ஜ์ & $4^{4}{ }^{7} 7^{7}$ & 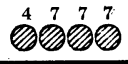 & 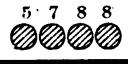 & ஜ2००० & 0000 \\
\hline
\end{tabular}


9 表ノ通リデアルガ. 此表二揭ゲタ實驗ハ第 2 表二揭ゲタ實驗ト同時二行ッタカラ. 大坼株二關スル成績八兩實驗二共通デアル。隨テ此株二關スル欄ハ再揭デアル。又參 考ノ篇メセントルーイス腦炎毒きモ併七試驗シタカラ・其成績き併記シテ置イタ。 此七ント・ルーイス毒八所謂 Webster，第三株デ．えレ亦三田村博士ョリ分與き受 ケタ。

此表デ見ル如ク抗馬腦炎毒血清八夏期腦炎毒 テ馬腦炎毒ト同樣ニ中和スルコト劣ホ 抗夏期腦炎毒血清，馬腦炎毒二於ケルト同一デァル。然ル二抗馬腦炎毒血清ハ七ント・ ルーイ ス腦炎青二對シ毫モ作用シナイ。尤モ一萬倍乳剂ノ處デ 2 匹人十日鼠ガ死き 免レ.又一般二生存日數ガ少シ延長シテ居ルガ.コレ八此際用七タ鬼 167 號血清八免疫 前カラ微量ノ馬腦炎毒隇殺物質キ有シテ居ツタカラ(第 1 表參照). 同ジ物質ノ作用二 歸スベキモノト考へラレル。今假リニえレナ抗馬腦炎性特異抗體二基ク顯象トシテモ 「カリニーナ」株ノ中和成績ト八格段ノ差ガアル。「カリニーナ」株ノ中和八無論抗馬腦 炎性特異抗體二基クモノデ．換言セバ夏期腦炎毒八馬腦炎毒卜同一抗元 同量二有ス ルモノト云フベキデアル。

\section{B. 交叉自働免疫試驗}

(1) 馬腦炎毒耐過動物 抗夏期腦炎毒免疫發生

大坪株馬腦炎毒キ腦內接種サレタ猿ノ內. 定型的ノ發熱キ來シタガ. 認ムべキ中心 神經症狀キ發顯七ズ二終ツタ者が 2 匹出來タ。此各々二馬腦炎毒接種後一ハ64日キ經 テ・他ノ一ハ26日キ經テ毒力十萬ノ「カリニーナ」二十日鼠 $10 \times$ 腦乳劑 1 c.c. 腦內接 種シタガ. 兩猿共何等ノ反應ガナカツタ(第 11,12 圖參照)。郎チ馬腦炎毒二輕ク感染 シタ動物ハ夏期腦炎毒二對スル免疫䅉ズル。

(2) 夏期腦炎毒耐過動物，抗馬腦炎毒免疫發生

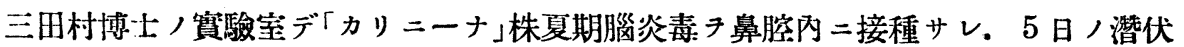
期于經テ發熱シ.次デ極メテ輕度ノ神經症狀郎チ．全身ノ輕微ナル振顫. 四趾ノ握力 ノ僅カナ減弱フ認メタガ. 是レ等八 5 日間見ラレタ丈ケデ．爾後健康二復シタ猿がア

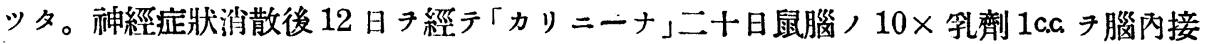
種シタガ全然反應ガナカッタ(第 13 圖參照)。郎チ鼻膑內接種ニヨリ輕微ナル感染 起シタ䉆メ二此猿八同名毒二對シテ免疫トナルコトガ確メラレタ。私共八三田村博士

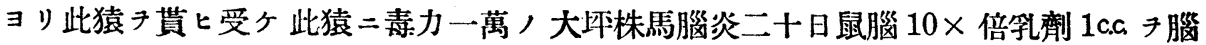
內接種シタガ. 又々無反應二終ツタ。郎チ夏期腦炎毒ブ耐過シタ篇メ二. 同毒二免疫 トナルト同時二馬腦炎素二對シテモ免度トナルコトガ立證サレタ。 

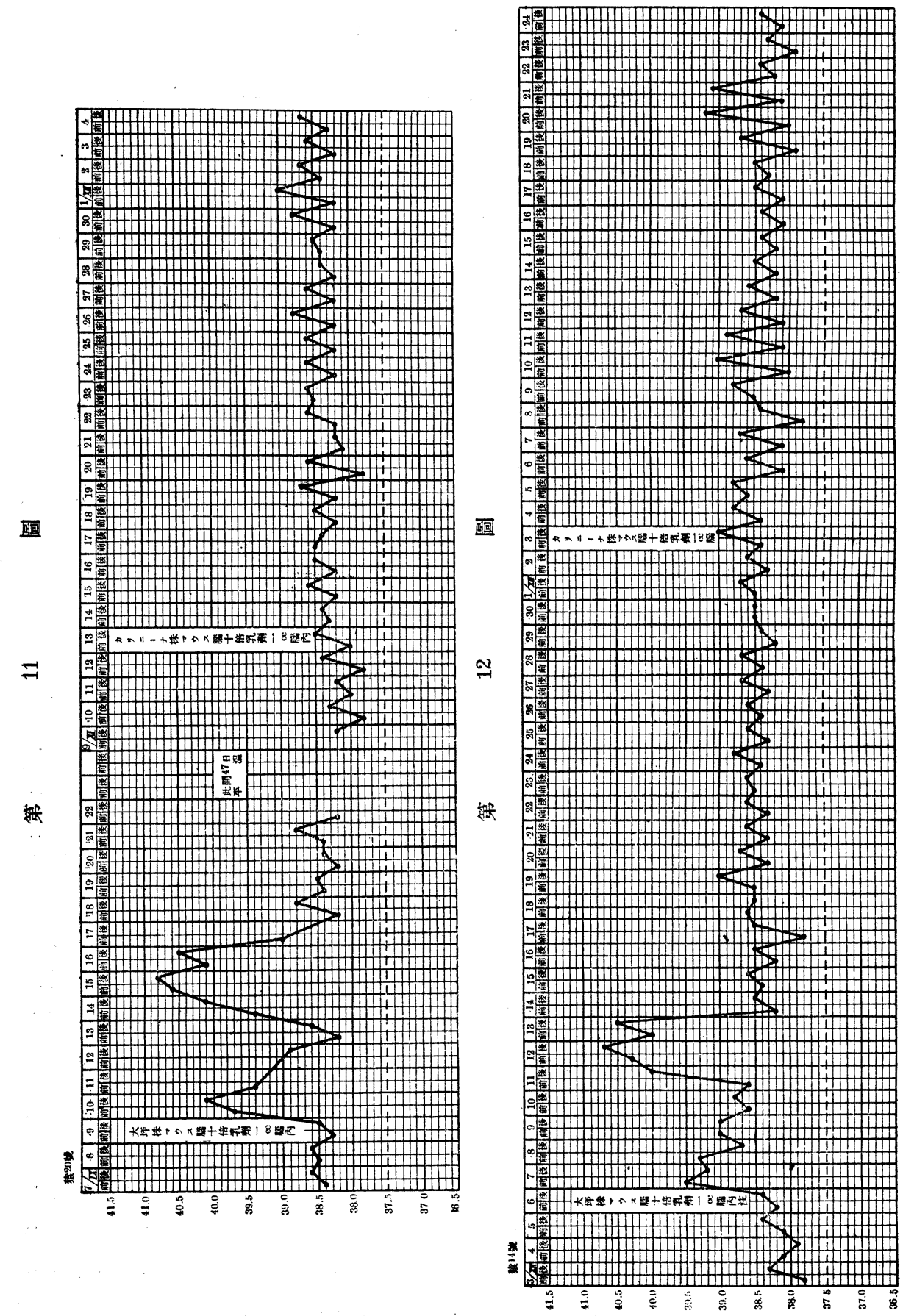


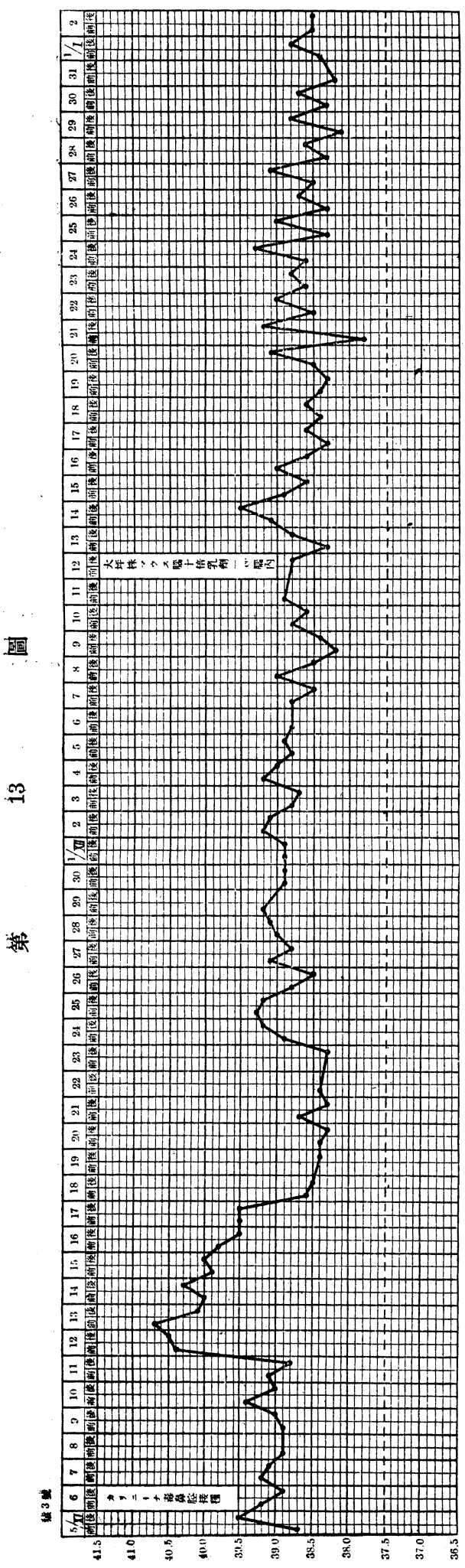

以上 4 種ノ賽驗ニヨリ私共ノ分離シ 夕馬腦炎毒八免疫學的二八人類ノ夏期 腦炎毒卜區別スルコト，出來ナイコト ア知リ得タ。之レニ由リテ之レテ見レ バ此兩毒八共二同一,モノカ.乃至八 少クトモ極メテ近緣ニアルモノト謂八 ネバナラヌ（私共ハ夏期腦炎毒き馬二 接種シテ見タ處ガ. 此馬八定型的ノ。 然カモ重篤ナル腦脊髓炎キ起シタ。コ レ八馬腦炎毒卜夏期腦炎毒卜，同定上 極メテ重要ナル件デアル。コレニ就テ 八稿改メテ報告スル)。

私共八第 II 章及ビ第 IV 章二於テ私 共ガ昭和 10 年杤木縣二於テ發生 シタ 腦炎患馬及ビ昭和 11 年筑後河沿岸二 於テ發生シタ同应患馬, 腦ヨリ分離シ タ病毒八何レモ同一ノモノデ. 而カモ 此病毒コソ是等腦炎ノ病原タルコトタ 論說シタ。然ル二此病毒八吾邦二特有 ナル人間）所謂夏期腦炎（又一二日本 腦炎トモ呼バレル），病原ト同一力。 若クハ少クトモ極メテ近緣二在ルモ， ナルコト以上ノ如シデアル。而シテ此 病毒ハドイツノボルナ病ノ病原「ヴ ルス」トモ。將丈アメリカノ馬腦脊髓炎 ノソレトモ其各種動物二對スル病原作 用ガ一致セ邓。隨テアルゼンチンニ發 生シタモノトモ異ナリ。恐ラク川品 シアノモノトモ違フノデアラウ。サス レバ吾邦ノ馬, 流行性腦炎八原因學的 見地ヨリスレバ是等卜ハ別個ノ疾病ナ 
リト謂ハネバナラ.ヌ。同時ニ若シモ此騳腦炎「ヴャールス」ガ私共ノ想像スル如ク人間 ノ夏期腦炎毒ト同一ナリトスルナラバ。日本ニハ人ト馬ト二共通二病原作用チ有スル 一種特異ノ腦炎「ヴャールス」ノ存スルコトガ明ニサレタコトニナル。若シ天レ自然界 二於テ此病毒二關シ人馬ノ間二如何ナル交涉ガ行ハレテ居ルカハ今後八殘サレタ重大 ニシテ且興味アル問題デアル。

\section{第 VI 章 非腦炎馬ヨリ腦炎毒ヨ分離シタル一例}

私共ガ昭和 11 年 8 月佐賀縣下二於テ 馬腦炎, 研究材料き 採取シッ、アル際. 矢張 同症，發生區域タル小城郡小城叮字晴氣. 中尾某秱有，6歲騄馬ガ肺壞疽二罹リ。8 月28日切迫屠殺, 䉆メ佐賀市營屠場二䢪ラレテ來タ。剖檢所見ノ主ナルモノ八兩肺ノ 壞疽. 顎凹淋巴腺及ビ咽背淋巴腺ノ化膿及ビ其周圍ノ漿液性浸潤デアッタ。主治獸醫 カラ聽キ得タ所デハ。本馬ハ 8 月 14-5 日頃カラ發病. 16日初唁. 賞時ノ主ナル症狀

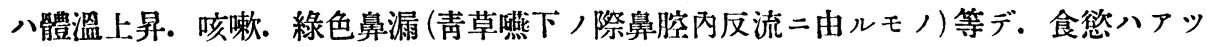
タ。咽頭炎卜診斷・水藥卜丸藥テ一劑宛與へテ歸シタ。2-3日チ經テ往診ノ際八體溫

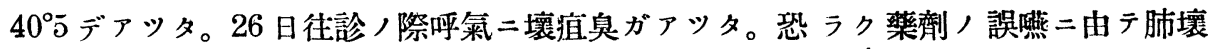
疽キ起シタモノデアラウ。初診以來毫モ腦炎症狀キ認メナカツタ云々。私共ハ此馬， 腦き無菌的二採取シ東京へ空輸シタ。其目的トスル所八肺壞誼八馬ノ腦炎二比較的頻 發/合併症デアルカラ(照下困難二由ル). 主治獸醫ノ否定二モ拘ラズ. 或八此馬カラ 組織學的又八動物接種ニヨリテ腦炎子證明シ得ル樣ナコトガアリハスマイカ. 若シソ レガ陰性デァッタナラバ. 流行地二於ケル非腦炎馬ノ腦デァルカラ。何カノ賽驗ノ對 照二利用スルニ都合ガヨイカモ知レヌト云フノデァツタ。

8 月 30 日東京二到著スルト直チ二前頭葉ノ一部チ食監水デ $10 \times$ 乳劑トナシ。とレ

第 14 圆 中尾株系圖 中 尾(組一)

$\otimes 000 \phi^{\circ} \mathrm{O} \phi^{6} \mathrm{O}$

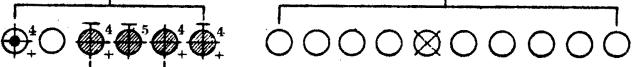

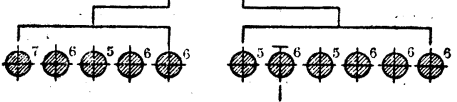
申
* 1 匹人馬. 1 匹, 猿. 5 匹 八鬼. 5 匹八海猽. 5 匹八大 黑鼠. 10 匹，二十日鼠二宮 原. 大坪兩株卜同樣二腦內接 種シタ。馬. 猿. 鬼. 海猽. 大黑鼠二八異常タ呈スルモノ ガナカツタガ. 意外二モ二十 日鼠/内二。變ナ死力キシタ モノガ出テ來テ．此内カラ第. 
14 圖ノ樣ナ經路デーツノ病毒ガ二十日鼠腦二固定サレタ。此病毒八抗大坼株血清二 ヨリテ完全二中和サレルカラ. 大坪. 信武. 朝霧. 宮原ノ各株ト同一ノモノデ刃ルコ トハ言タ俟タナイ。其中和試驗ハ第 2 表ノ實驗〉際同時ニナサレタカラ. 同表中二併 記シテ置イタ，中尾株ト云フノガソレデアル。然ルニ以上動物接種試驗ト本行シテ腦 ア組織學的二精檢シタガ. 如何ニシテモ腦炎刃八脊髓炎,變狀ガ認メラレナカッタ。 隨テ主治獸醫ノ陳述卜併七考へルト，少クトモ屠殺當時二八腦炎八存在シナカツタモ ノト言ハネバナラヌ。

此事實ハ之レタ如何二說明スベキ乎。論者或ハ謂ハン。此事實コソ私共ノ分離シタ ル病毒ノ流行性腦炎病原說き否定スベキ好材料デァルト。然シ私共八第 IV章二於テ 述べタ理由ニヨリ. 此病毒八吾邦ノ馬ノ流行性腦炎ノ病原體タルコトチ固ク信ズルカ ラ. 最早此ノ如キ說ニ耳キ傾ケル餘地ガナイ。ソコデ私共ハ次ノ 3 個ノ場合タ想像 ル。第 1 八本馬八肺壞痽ヤ.其原病ト思ハレル咽頭炎ト八無關係二腦炎二感染シ.恰モ 其潛伏期中ニアツタコト. 第 2 八以上/疾病卜同時二腦炎, 無症狀感染ガ成立シテ居

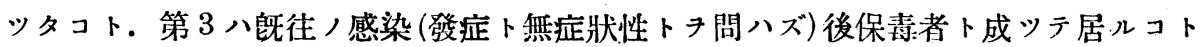
デアル。第 1 及ビ第 2 八强チ無理ナ想像デハナイト信ズルガ. 第 3 二就テハ直チ二之 レォ首肯スルコトチ躊躇サレル讀者ガ少クナイト思ハレル。ソレニモ拘ラズ私共ハ寧 ロ最後ノ假說最モ有力視シテ居ルノデアル。ト云フノ八本馬ノ棲息シテ居ツタ地方 デハ本馬ノ如キ年龄二達セルモノガ初メテ腦炎二罹ルト云・コトハ蜜口破格デァル。 ソレハ次ノ表タ見レバ制ル。

第 10 表 佐賀縣腦炎患馬年跲別

\begin{tabular}{|c|c|c|c|c|c|c|c|c|c|c|c|c|}
\hline 年次 年盎 & 當歳 & 2 歳 & 3 藏 & 4 歲 & 5 藏 & 6 蔵 & 7 歳 & 8 歳 & 9 歳 & 10歲 & $\mid \begin{array}{l}10 \text { 歲 } \\
\text { 以上 }\end{array}$ & 計 \\
\hline 昭和 10 年 & 0 & 32 & 5 & 0 & 1 & 0 & 0 & 0 & 0 & 0 & 1 & 39 \\
\hline 昭和 11 年 & 1 & 72 & 30 & 11 & 2 & 2 & 1 & 0 & 0 & 0 & 1 & 122 \\
\hline
\end{tabular}

以上ノ表キ見ルト。佐賀縣デ腦炎二罹ル馬ハ殆ンド 2 歲及ビ 3 歲二限ルト謂ツテ大 過ナイ。コレハ何キ物語ツテ居ルカ。本症八此ノ如キ幼龄馬ノ $i$ 侵力 ス疾病乎。然 ラズ。昭和 10 年二初メテ本症二襲ハレタ地方デハ概シテ若傌が多ク罹患セルコト 八否そ得ナイガ. 然シ 4 歲以上ノ馬デえレニ罹ツタモノガ幾ラデモアル。罹患軍馬 ノ大部分ハ 6 歲. 7 歲デ刃几(軍隊ニ八夏期ニ於テ 6 歲以下，馬八原則トシテハ 1 頭 モ居ナイ。そレ年朱二5歲, 新馬ナ軍馬補充部ヨリ補充サレルカラデアル。仯木吾邦

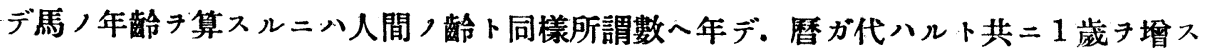
ノデァル)。然ラベ佐賀縣ディ何故二制然ト患馬ノ殆ンド凡テガ 2 歲及ビ 3 歲二限ル 
ト云フガ如キ統計ガ得ラル、ノデアルカ。コレハ年龄,關係ヨリモ塞口同地方二輸入 サレテカラノ經過年月キ示シテ居ルノデアル。由來佐賀縣下デ八馬ハ殆ンド生產シナ 1。之レニ反シテ同縣ノ本坦地方八北儿州ニ於ケル重要ナル馬匹有成地デアル。農家

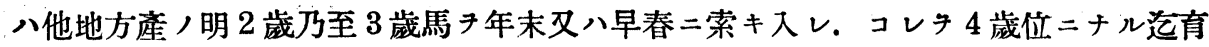
成シテ他地方へ䝴り出スノガ古來ヨリノ習慣デァル。所デ夏ニナッテ腦炎二罹ルモノ 八此新二荦キ入レラレ. 同地方デ始メテ夏二出遇フタ育成中/幼駒二殆ンド限ラレテ 居ル。ソレ故二患馬ノ年齡別統計ガ上揭ノ如クナルノデァル。因二此表デ見ラレル如 ク. 當歲馬ノ患馬ノ殆ンドナイノ八同地八馬產地デナイカラ. 夏期二於テ腦炎ノ發生 スル季節ニ八當歳馬ガ縣下二殆ンド絕無ナル篇メデアル(江本博士 ${ }^{(2)}$ 等 報告キ見ル ト.昭和 10 年，大流行ノ際二於ケル栃木縣下，患馬，年齡別統計モ此佐賀縣ノソレト 殆ンド全ク同一デァル。コレハ佐賀縣ト同一事情ニアル篇メニカ、ル統計ガ得ラレタ ノデァルカ．私共ハ未沫調ベテナイ。何レニセヨ本問題ト直接關係ノナイコトデアル カラ弦デハ深ク論究シナイ)。此ノ如ク佐賀縣下デハ腦炎二罹儿馬, 大部分八輸入後 最初ノ夏キ經過スルモノデアルニ拘ラズ。本壞誼患馬八昭和 6 年生レノ 6 葴琵デアッ テ.久シク以前ヨリ此地二在ツタモノデァル。斯ル馬トテ決シテ腦炎二罹ルコトナシ ト八蹊定出來ナイケレドモ．鬼二角罹患ノ公算ノ少イコト八確カデァル。サスレバ昭 和 11 年, 夏ニナッテ初メテ本症二罹ツテ. 恰モ潛伏期中二在ツタトカ. 或八同年, 夏初メテ無症狀感染テ蒙ツタト見ルヨリモ。塞口輸入直後二感染子蒙り．爾來保毒者 トナツテ居ツタト考へル方ガ. ヨリ眞賽二近イヤウ二思ハルノデァル。以上八單二消 極的ノ立諭デハアルガ. 他二確カナ立證的ノ說明ガッカナイ限り．第 3 人如キ狀態き 一應想像シテ見ルコト八當然許サルベキデァル。事ニヨレバ本症，常在地二八斯クノ 如キ保毒馬ガ相當數二存在スルノデハナカラウカ。私共ハ將來コレチ研究シタイト思 フテ居ルノデァルガ.トマレ私共ノ經驗シタ事實キ陳ベテ同學ノ參考二供スル。

\section{第 VII 章 結 論}

(1) 昭和 10 年栃木縣下二於テ發生シタル 2 頭 ノ腦炎患馬 /全部及ビ昭和 11 年佐賀 䍘下筑後河沿岸二於テ發生シタル同症患馬 3 頭中 2 頭. 郎チ合計 5 頭中 4 頭 /腦ヨリ 一種ノ「ヴッールス」チ分嚾シタ。

(2)以上 4 頭／患馬ヨリ分離シタル「ヴ

（３）此「ヴャールス」ハBerkefeld V 滤過器き容易二通過シ。「グリセりシ」闬性デ アル。 
(4) 此「ヴキールス」八馬ノ外. 二十日鼠及ビ赤毛猿 (Macaca rhesus) 二病原作用 有シ。其腦內二注入スルト．腦炎及ビ脊髓炎フ起ス。家鬼. 海猽及ビ大黑鼠二對シテ 八病原作用ガナイヤウデァル。

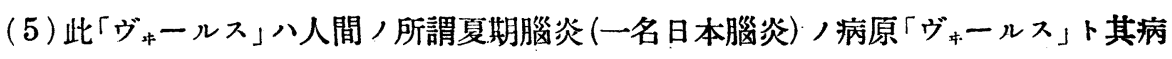
原作用ガ全然一致シ (夏期腦炎毒八馬二對シテ病原作用ガアル)且ツ免疫學的二八互二 湂別スルコトガ出來ナイ。故二是等兩病毒八共二同一ノモノカ. 若クハ少クトモ極メ テ近緣ニアルモノト謂ハネバナラヌ。

(6) 此「ヴャールス」コソ吾邦ノ馬ノ流行性腦炎ノ病原體デアル。隨テ

(1) 昭和 10 年夏. 殆ンド全國ニ瓦ツテ大流行チ起シタ馬腦炎ト. 筑後河沿岸地 方二常在シ. 每年夏地方病性二發生スル馬腦炎卜八同症デアル。

(口)本邦，馬腦炎卜同一病原體ニョリテ起ル馬腦炎ハ何レノ國ニ於テモ未ダ發見 サレナイカラ．原因學的二見テ本邦ノソレ八特殊ノモノデアル。

(7) 佐賀縣下, 馬腦炎常在地二於テ 1 頭ノ毒保有馬ラシキモノチ發見シタ。

擱篗二當り一昨年私共ガ本研究于開始シタ當初カラ. 特二多大ノ獎勵卜鞭撻卜援助 トチ辱フシタ宮川傳染病研究所長二謝意卜敬意チ表シ。色々貴重ナル研究材料チ分與 サレ. 或ハ多數, 賽驗用馬匹,使用き許可サレタ陸軍省騎兵課及ビ陸軍獸醫學校ノ當 局各位就中官本課員. 矢嶋病馬廠長. 市井. 若松. 辻ノ各教官二感謝スル。更二三田 村部長

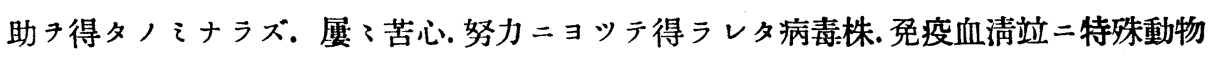
タ喜ンデ分與セラレタ好意二對シテ滿腔/謝意タ表スル。佾ホ昭和 11 年夏私共ガ佐 賀縣下二於テ研究材料菟集二當リ. 種々ナル方面二向ツテ奔走ト援助. 協力キ惜マレ ナカッタ大須賀縣衙生課長. 奧山技師及ビ横堀. 佐々. 北ノ各技手二厚ク感謝スル。

最後二本研究二當り日本學術振興會ノ援助タ受ケタコトタ立二述べテ置ク。

\section{引用文畩}

1) Zwick und Seifried, Berl. Tierärztl. Wschr. 1925, S. 192.

2) Zwick, Seifried und Witte, Zschr. f. Infekt. Kr. d. Haustiere. Bd. 30, 1926, S. 42.

3) Ernst und Hahn, Münch. Tierärztl. Wschr. 1926, S. 46.

4) Nicolau and Galloway, Med. Research Council, special report, No. 121, 1928.

5) Moussu et Marchand, Recueil de Med. vét. T. 100, p. 5 et 65.

6) Arndt, Zschr. f. Infekt. Kr. d. Haustiere, Bd. 29, 1926, S. 184.

7) Meyer, Haring and Howitt, Journ. Amer. Vet. Assoc. Vol. 79, 1931, p. 376.

8) Howitt, Journ. Immun. Vol. 29, 1935, p. 319.

9) Ten Broeck and Merril, Proc. Soc. Exper. Biol. \& Med. Vol. 31, 1933, 2. p. 217. 
10) Rosenbusch, Zschr. f. Infekt. Kr. d. Haustiere, Bd. 47, 1934, S. 1.

11) Chluszow und Rostegajewa; Deut. Tierärztl. Wschr. 1935, S. 484.

12）江本, 近藤, 渡邊, 松本, 家音衙生協會報. 第四年 (昭和 11 年). 第 2 號. 123 頁.

13）市井, 若松, 加藤, 陸軍獸醫團報. 第 327 號 (昭和 11 年 10 月). 1 頁.

14) 三由村, 北岡, 渡邊, 大久保, 天神，東京醫事新誌. 3006 號(昭和 11 年). 3149 頁.

15) Theiler, Science, Aug. 5, 1934.

16) Traub, do, March. 22, 1935.

\section{附 圖 說 明}

\section{圖版 I}

圖 .1. 馬腦炎毒大坪株腦內接種二十日星 898 號。猬型。

圖 2. 同上 1006 號。猬型。

圖 3. 同上 898 號。「カンガルー」型。

圖 4. 同上 1791 號。誘起 $=\Xi$ 擧尾站二全身症攣。

圖 5. 同上 1789 號. 䐚痹後肢ヨリ始マル。

圖 6. 同上 3370 號。麻瘰前肢ヨリ始マル。

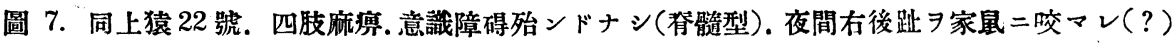
大頁傷入, 知覺脱失, 篇又? 運動不隨, 雼又?

\section{圖版 II}

圖 1. 馬腦焱毒大坪株腦內接種二十日鼠 1153 號腦䯕。「ヘマトキシリンーエオシンン染色. 接 物鏡 Zeiss AA Apochromat. 接眼鏡 Zeiss Projektionsokular $2 \times$. 蛇腹長 $50 \mathrm{~cm}$. P.V-I = 血管 周圍細胞浸洞。右上隅二輕度, 軟腅膜炎。

圖 2. 圖 1 卜同一標本. 接物鏡 Zeiss DD Apochromat. 接眼鏡 Zeiss Periplan 5×. 蛇腹長 $30 \mathrm{~cm}$ ，中央二血管周圍細胞浸潤。

\section{圖版 III}

圖 1. 馬腦炎毒大坪株腦內接種猿 22 號腰䯕。「へマトキシリンーエオジン」染色. 接物鏡 Zeiss AA Apochromat. 接眼鏡 Zeiss Projektionsokular $2 \times$. 蛇腹長 $70 \mathrm{~cm}$. P.V.I $=$ 血管周圍細胞浸 潤. $\mathrm{GL}=$ 膠質細胞結節。

圖 2. 圖 1 ，P.V-I 部强擴大. 接物鏡 Zeiss DD Apochromat. 接眼鏡 Zeiss Projektionsokular $2 \times$. 蛇腹長 $30 \mathrm{~cm}$ 。

圖 3. 圖 1 ，GL 部强擴大. 接物鏡 Zeiss DD Apochromat. 接眼鏡 Zeiss Projektionsokular $2 \times$. 蛇腹長 $30 \mathrm{~cm}$ 。

\section{圖版 IV}

圖 1. 馬腦焱毒大坪株腦內接種馬盤坂號尾狀核。「ヘマトキシリンーエオシン」染色. 按物鏡 Zeiss AA Apochromat. 接眼鏡 Zeiss Projektionsokular $2 \times$. 蛇腹長 $65 \mathrm{~cm}$. P.V-I=血管周圍細 胞浸潤. $\mathrm{GL}=$ 膠質細胞結節。

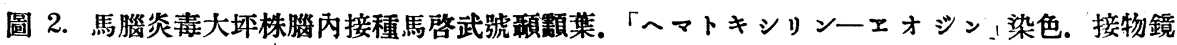
Zeiss $8 \mathrm{~m}$. Apochromat. 接眼鏡 Zeiss Projektionsokular $2 \times$. 蛇腹長 $36 \mathrm{~cm}$, P.V.I =血管周圍細 胞浸潤. $\mathrm{GL}=$ 膠筫細胞結節。 
城井外六名論文附圖 (I)

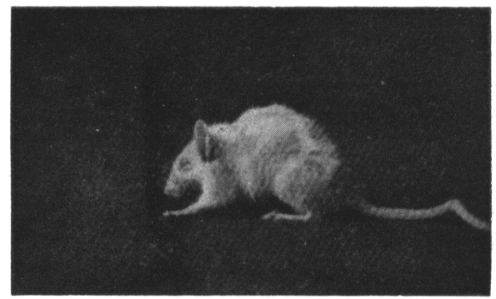

圖 1 .

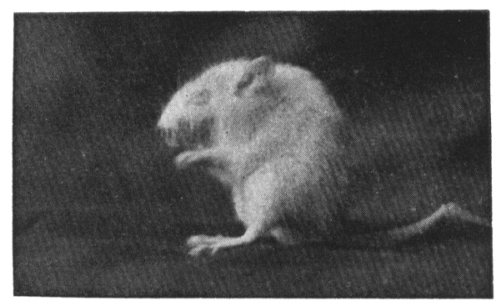

圖 3 .

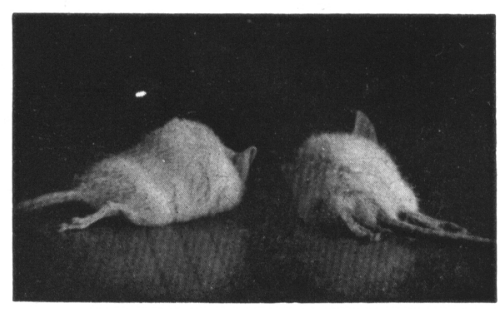

圖 5 .

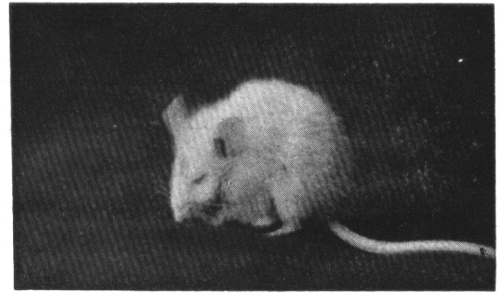

圖 2 .

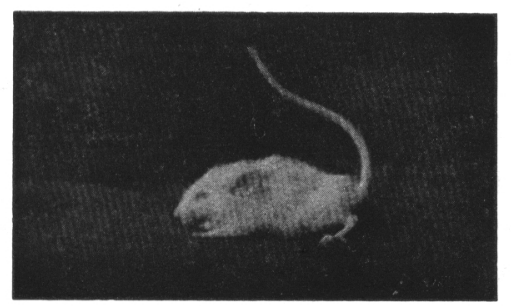

圖 4 .

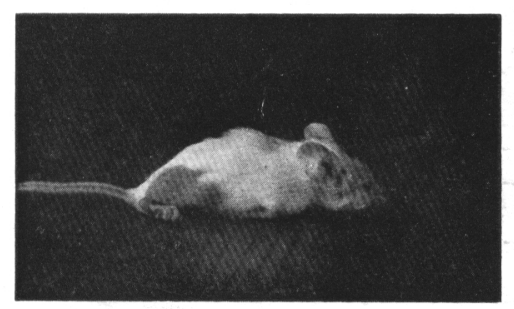

圖 6.

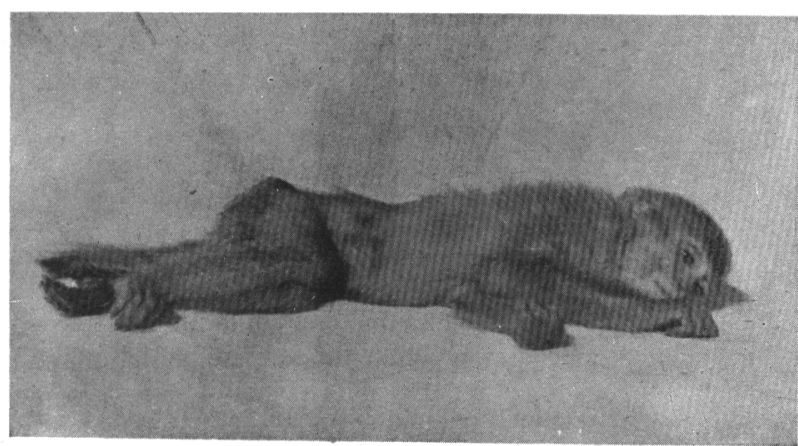

圖 7 . 
城井外六名論文附圖 (II)

P- V-I

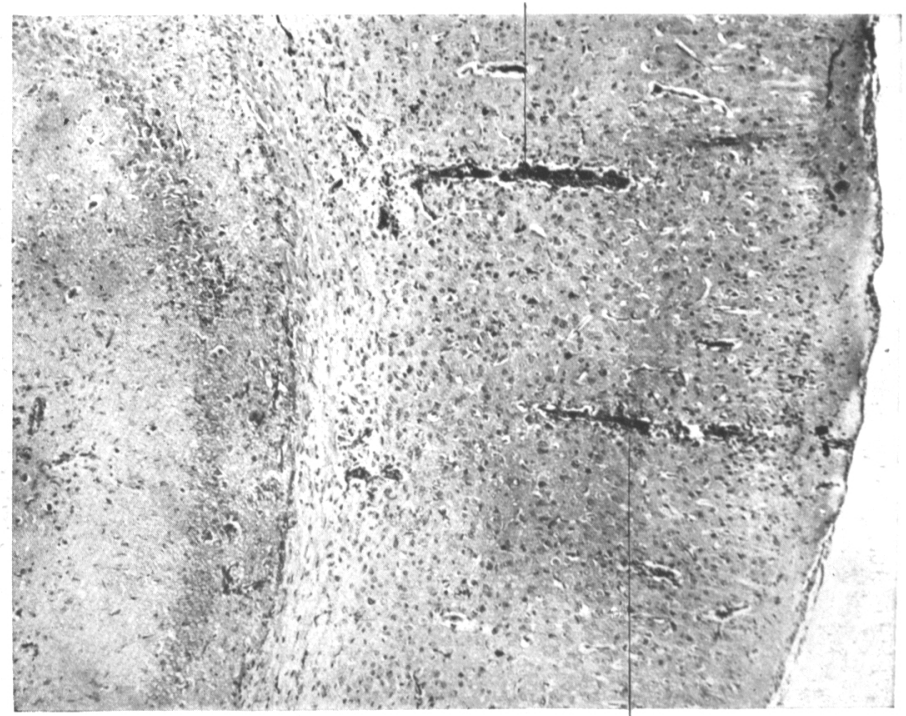

$\mathrm{P}-\mathrm{V}-\mathrm{I}$

圖 1 .

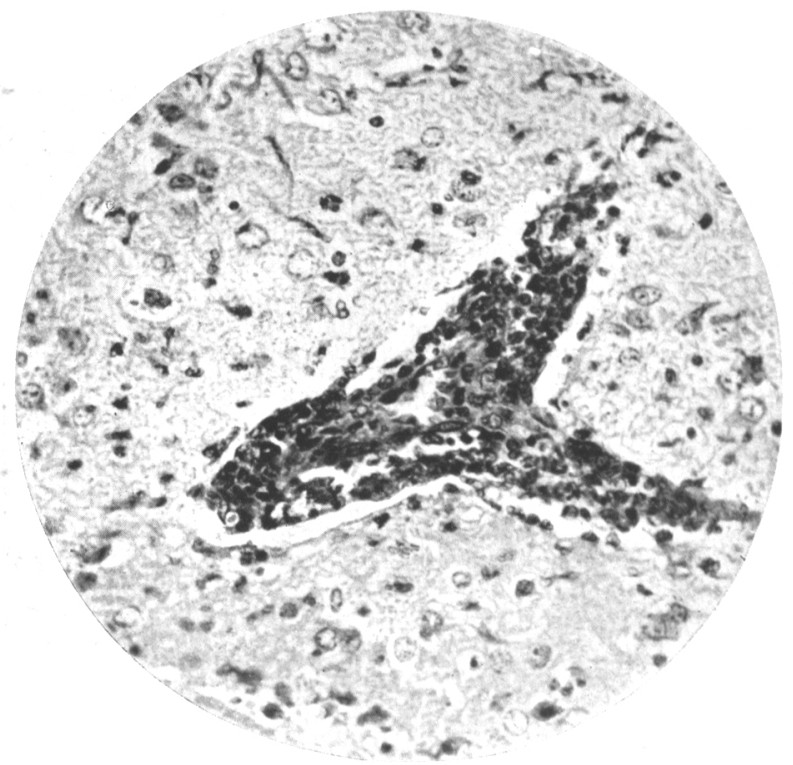

圖 2 . 
城井外兵名論文附圖 (III)

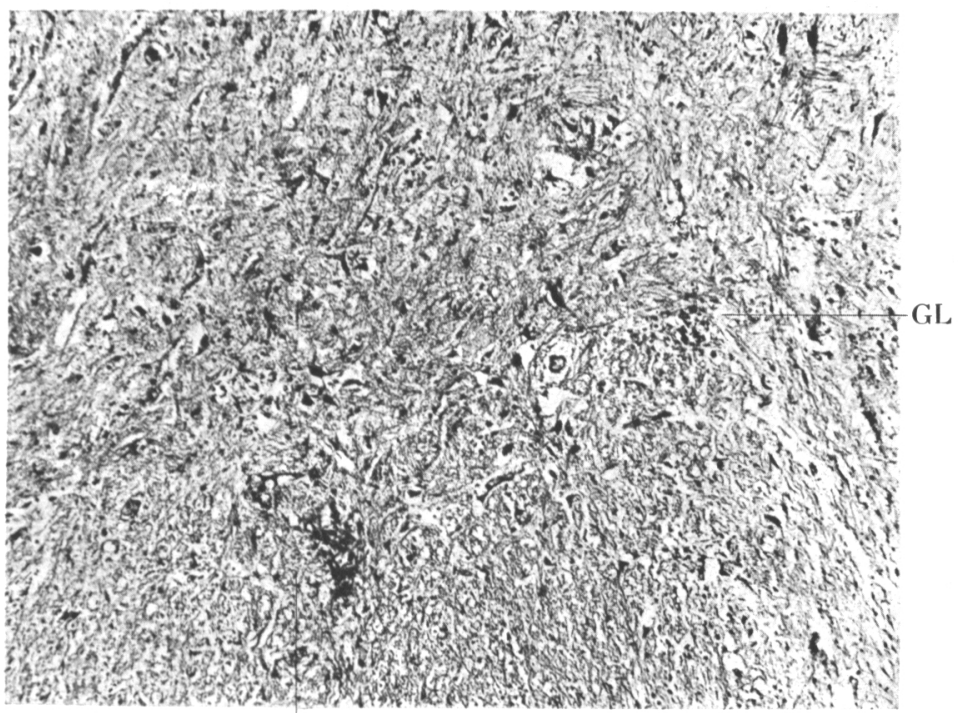

P-V-I

圖 1 .

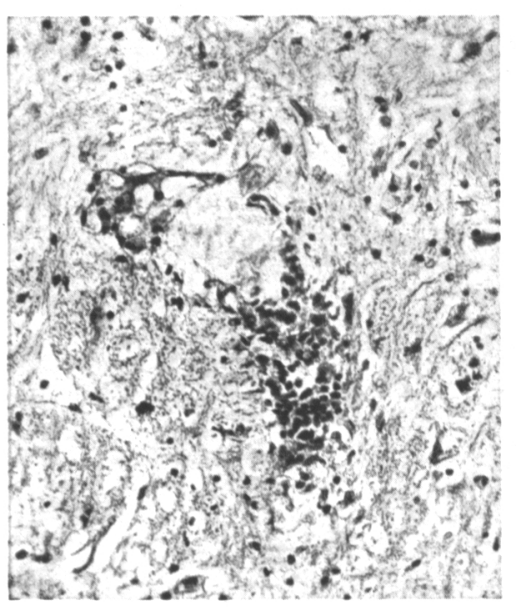

回 2 .

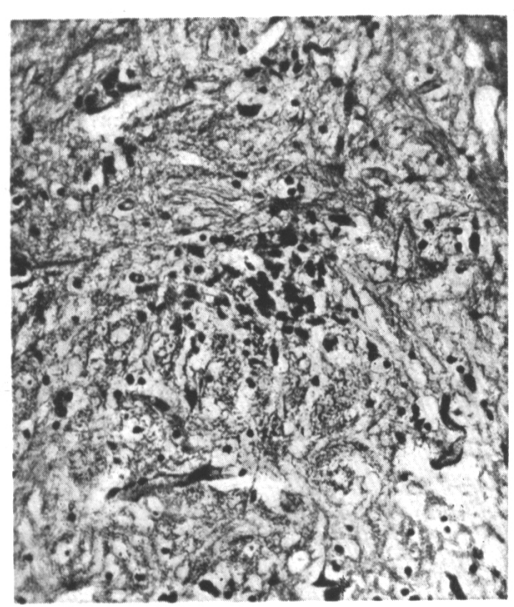

圖 3 . 
城井外六名論文附圖 (IV)
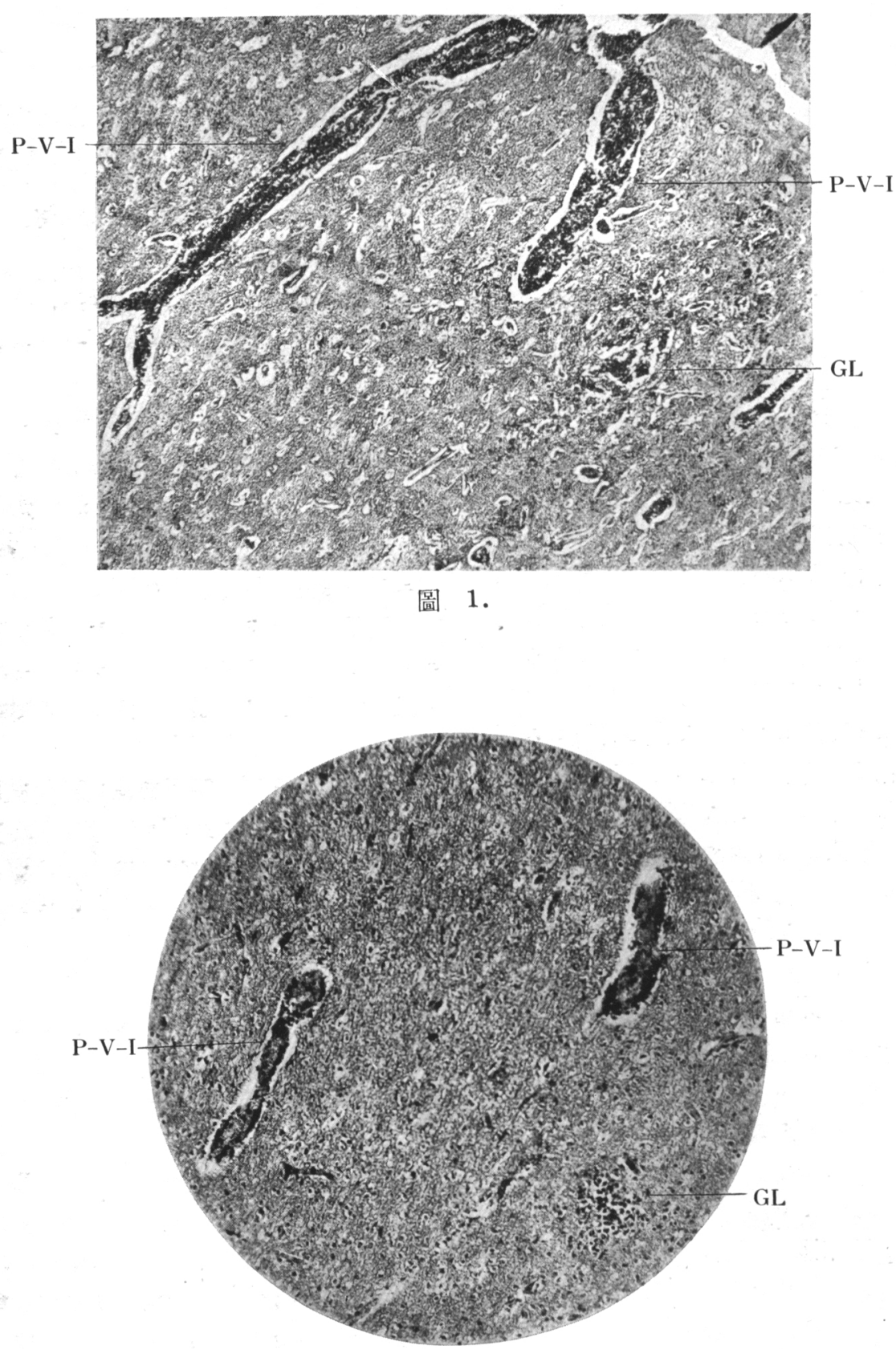

圖 2 . 